\title{
Assessment of the characteristic of nutrients, total metals, and fecal coliform in Sibu Laut River, Sarawak, Malaysia
}

\author{
Chen-Lin Soo $\cdot$ Teck-Yee Ling $\cdot$ Nyanti Lee $\cdot$ \\ Kasing Apun
}

Received: 1 November 2013/ Accepted: 21 May 2014/Published online: 12 June 2014

(C) The Author(s) 2014. This article is published with open access at Springerlink.com

\begin{abstract}
The concentrations of nutrients (nitrogen and phosphorus), total metals, and fecal coliform (FC) coupling with chlorophyll- $a$ (chl- $a$ ), 5-day biochemical oxygen demand $\left(\mathrm{BOD}_{5}\right)$ and other general environmental parameters were evaluated at the sub-surface and near-bottom water columns of 13 stations in the Sibu Laut River during low and high slack waters. The results indicated that inorganic nitrogen (mainly nitrate) was the primary form of nitrogen whereas organic phosphorus was the major form of phosphorus. The abundance of total heavy metals in Sibu Laut River and its tributaries was in the order of $\mathrm{Pb}<\mathrm{Cu}<\mathrm{Zn}<\mathrm{Cd}$. Fecal coliform concentration was relatively low along Sibu Laut River. The shrimp farm effluents contributed a substantial amount of chl- $a, \mathrm{BOD}_{5}$, nutrients, and FC to the receiving creek except for total metals. Nevertheless, the influence was merely noticeable in the intake creek and amended rapidly along Selang Sibu River and brought minimal effects on the Sibu Laut River. Besides, the domestic sewage effluents from villages nearby also contributed a substantial amount of pollutants.
\end{abstract}

\section{C.-L. Soo $(\bowtie) \cdot$ T.-Y. Ling}

Department of Chemistry, Faculty of Resource Science and

Technology, Universiti Malaysia Sarawak, 94300 Kota

Samarahan, Sarawak, Malaysia

e-mail: qianlin1112@gmail.com

N. Lee

Department of Aquatic Science, Faculty of Resource Science and Technology, Universiti Malaysia Sarawak,

94300 Kota Samarahan, Sarawak, Malaysia

K. Apun

Department of Molecular Biology, Faculty of Resource Science and Technology, Universiti Malaysia Sarawak,

94300 Kota Samarahan, Sarawak, Malaysia
Keywords Waterquality-Eutrophication·Heavymetals. Fecalcoliform·SibuLautRiver

\section{Introduction}

Deterioration in water quality is one of the greatest concerns associated with population growth and accompanying land-use changes (Ribeiro and Kjerfve 2002; Davis and Koop 2006; Ham et al. 2009; Whitall et al. 2010; Hadibarata et al. 2012). Eutrophication, metals contamination, and bacterial pollution are among the major problems and stresses of the marine environment and have been receiving global attention and interest (Malik and Ahmad 2002; Parnell 2003; Jonas and Millward 2010; Reopanichkul et al. 2010; Shin et al. 2012).

Eutrophication can be defined as the process of increasing nutrients of an ecosystem that causes changes to its nutritional status (Nixon 1995). Most frequently, this has usually been characterized by increased supplies of nutrients in particular nitrogen and phosphorus to that system, although the supply of excessive decomposable organic carbon leads to eutrophication as well (Young et al. 1999; Pinckney et al. 2001; Howarth and Marino 2006). The discharge of excessive nutrients from urban and industrial wastewaters, or rural and agricultural runoff contributes to the enrichment of inorganic and organic material in marine waters. Eutrophication can lead to the detrimental changes of the structure and function of both living organisms and non-living components in an ecosystem (Paez-Osuna et al. 1998; Bricker et al. 1999; Smith et al. 1999; Meyer-Reil and Koster 2000; Parnell 2003; Del-Pilar-Ruso et al. 2009; Reopanichkul et al. 2010). Often, the "bloom" or greatly increase of aquatic vegetation or phytoplankton and algal in a water body is the first 
response to the increased levels of nutrients or the eutrophication (Pan and Subba Rao 1997; Smith et al. 1999). Hence, chl- $a$ concentration which provides a measure of phytoplankton biomass often used as an indicator of eutrophication and studied along with nutrients (Ho et al. 2008; Xu et al. 2008; Madhu et al. 2010; Lefebvre et al. 2011).

Besides nutrients, excessive amounts of heavy metals have been introduced to estuarine and coastal environments as a result of intense industrial development and anthropogenic activities (Fianko et al. 2007; Nduka and Orisakwe 2009; Sundaray et al. 2012; Zhang et al. 2012; Lacerda et al. 2013). Heavy metals are deemed to be dangerous pollutants and have raised environmental concern due to their toxicity, persistence and non-degradability, bioaccumulation in organisms, and ultimately their effect on human health (Burgos and Rainbow 2001; Kress et al. 2004; Otero et al. 2005; Kurun et al. 2007; Du Laing et al. 2008). Special attentions have been paid to $\mathrm{Cd}, \mathrm{Cu}, \mathrm{Pb}, \mathrm{Zn}$ and many other heavy metals.

The discharge of domestic and industrial wastewaters with the presence of pathogenic microorganisms in the adjacent water frequently threatened the microbiological quality of the water (Aslan-Yilmaz et al. 2004; Nduka and Orisakwe 2009; Dorsey et al. 2012). The microbiological risks depend on the bacteria concentration in water and on the water usage such as drinking, recreational activities, irrigation, and shellfish harvesting purposes. The microbiological quality of water is classically monitored by searching for and quantifying bacterial indicators of fecal contamination. Total coliform, fecal coliform, fecal streptococci and enterococci are among the most frequently used microbial indicators of fecal pollution (Malik and Ahmad 2002; Cabral and Marques 2006; Djuikom et al. 2006; Kovačić et al. 2011). Although not usually harmful themselves, their presence may indicate the possibility of pathogen presence (Bonadonna et al. 2002; Dorsey et al. 2012).

Sibu Laut River is surrounded by various villages, shrimp farms and tourism's activities make it vulnerable to human activities and susceptible to water quality degradation. Furthermore, Sibu Laut River, which forms the western boundary of the Kuching Wetlands National Park, a wetland classified as a sensitive area also renders it of high research value. What happened to Sibu Laut River and its tributaries now? Is Sibu Laut River suffering from eutrophication, metals contamination or bacterial pollution? The level and the variability in the water quality over neap-spring tidal cycles in this river are yet to be explored in detail. Hence, physicochemical and major water quality data were collected and were employed to determine the water quality characteristics and current health status of the Sibu Laut River and its tributaries. The data presented here provide a snapshot of hydrodynamic conditions and water quality of the Sibu Laut River and its tributaries experienced during high and low tides.

\section{Materials and methods}

Study area and sampling regime

The Sibu Laut River is in the northwest region of Kuching, Sarawak, Malaysia (Fig. 1). The area experiences a humid tropical climate with an annual rainfall of $3,600-4,000 \mathrm{~mm}$. The region is not directly exposed to the northeast monsoon. Rainfall is the lowest during June and July, and reaches a peak in December and January. Temperature ranges from 19 to $36{ }^{\circ} \mathrm{C}$ receives only $5 \mathrm{~h}$ of sunshine per day on average (Malaysian Meteorological Department 2012). This river is one of the boundaries of the Kuching Wetlands National Park at which the international importance of the wetland has been recognized when Malaysia designated the park as the RAMSAR site in November 2005 (Ramsar Site No., 1568), which is also the first Ramsar site in Sarawak and the fifth in Malaysia (Wetlands International 2013). The river drains the mountainous region at the upper reaches of the wetland and the mangrove swamp within the delta on the estuary with tidal ranged from 0.0 to $4.7 \mathrm{~m}$. Selang Sibu River and Loba Kilong River are the left and right tributary at the downstream of the Sibu Laut River.

Samplings were divided into two stages. Stage one focused on the eutrophication study while stage two concentrated on heavy metals and bacteriological water quality. Table 1 shows the details of the sampling cruises. Four samplings were conducted to obtain the data of nutrients in 2010 while two samplings were conducted for total heavy metals and bacteriological water quality study in 2011. A total of 13 stations was selected along Sibu Laut River and tributaries (Fig. 2). The total river length studied was approximately $8 \mathrm{~km}$. The locations were chosen mainly due to their proximity to the suspected domestic pollution sources and aquaculture activities; and some relatively unpolluted sites as a control. The distance between stations was ranged from 1 to $2 \mathrm{~km}$. The first station was at the most downstream of the river. Station 2 was in the Loba Kilong River near to the village of Sibu Laut, just before its conjunction with Sibu Laut River. Station 3, 4, and 5 were along the Selang Sibu River. Station 5 was the closest site to the discharge point of a shrimp farm (Sea Horse Marine Life Sdn. Bhd.). These stations are intended to monitor the possible impacts of the discharges of wastewater and the influences to the tributary and main river body. Stations 6 , 7,8 , and 9 were along the main river body of Sibu Laut. Station 6 was chosen to observe the possible influences from the surrounding activities of the Telaga Air Town and 
Fig. 1 Study area

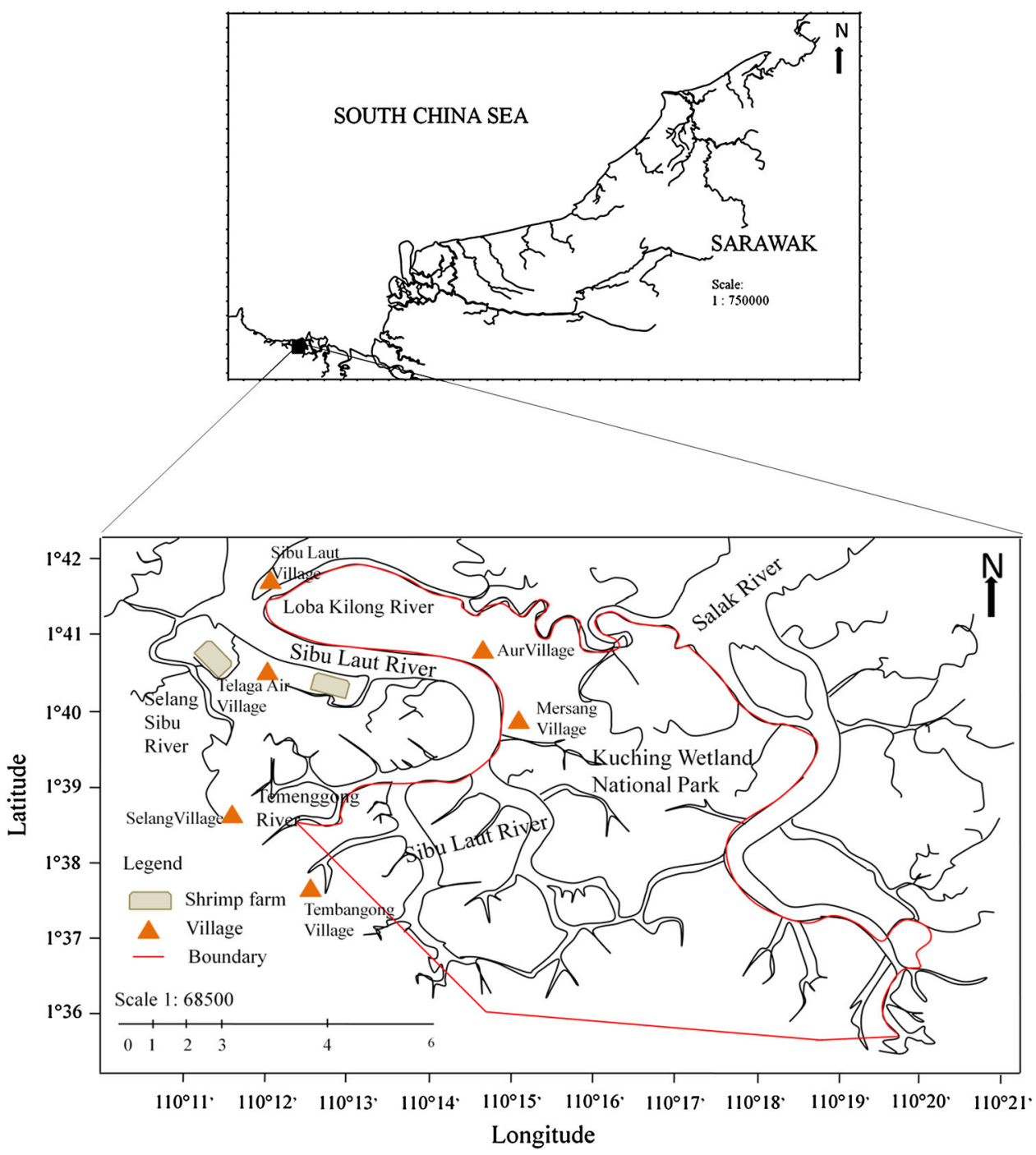

Table 1 Details of the sampling cruises

\begin{tabular}{|c|c|c|c|c|}
\hline Sampling & Date & Tide & $\begin{array}{l}\text { Water } \\
\text { column }\end{array}$ & Parameters \\
\hline 1st trip & 25.2 .10 & High & Near-bottom & \multirow{4}{*}{$\begin{array}{l}\text { General environmental } \\
\text { parameters, nutrients, } \\
\text { chl- } a, \mathrm{BOD}_{5}\end{array}$} \\
\hline 2nd trip & 25.3 .10 & High & Sub-surface & \\
\hline 3rd trip & 29.4 .10 & Low & Near-bottom & \\
\hline 4th trip & 18.5.10 & Low & Sub-surface & \\
\hline 5 th trip & 16.6 .11 & Low & $\begin{array}{l}\text { Sub-surface } \\
\text { and Near- } \\
\text { bottom }\end{array}$ & $\begin{array}{l}\text { General environmental } \\
\text { parameters, total heavy } \\
\text { metals, and fecal coliforr }\end{array}$ \\
\hline 6th trip & 27.7.11 & High & $\begin{array}{l}\text { Sub-surface } \\
\text { and Near- } \\
\text { bottom }\end{array}$ & \\
\hline
\end{tabular}

the public jetty. Station 7 was close to another shrimp farm belonging to CCK Pelita Telaga Air Sdn. Bhd. Station 8 and 9 were near to the village of Aur and Mersang, respectively. Station 10 and 11 were at the right upstream



Fig. 2 Sampling stations along the Sibu Laut River and its principal tributaries 
while station 13 was at the left upper reach of the Sibu Laut River near to Tembangong Village. Station 12 was at the Temenggong River, which is the left upper tributary of the Sibu Laut River.

\section{Sampling techniques}

Portable Global Positioning System (GPSMAP $^{\circledR} 76 \mathrm{CSx}$, GARMIN) was used to determine the actual coordinates of the sampling stations and to re-confirm the location of the stations during subsequent sampling periods. Hydrological parameters including salinity, $\mathrm{pH}$, temperature, dissolved oxygen (DO), turbidity, and transparency were measured using a refractometer (MR100ATC, Milwaukee), a $\mathrm{pH}$ meter with temperature probe (HI 8424, Hanna), a DO meter (HI 9142, Hanna), a turbidity meter (HI 93703, Hanna), and a secchi disc with measuring tape, respectively. Temperature, $\mathrm{pH}, \mathrm{DO}$, total dissolved solids (TDS), and conductivity were measured using a multi-parameter water quality meter (PCD650, Eutech) for samplings conducted in stage two samplings in the year 2011.

In stage one sampling for nutrients study, three replicate water samples were taken from the sub-surface and nearbottom water columns using a 2-1 Wildco ${ }^{\circledR}$ Van Dorn water sampler. The water sample was taken in the middle of the river with approximately $1 \mathrm{~m}$ below the surface water and $1 \mathrm{~m}$ above the river bed after confirmed the river width and depth using a rangefinder (Elite 1500, Bushnell) and a depth sounder (PS-7, Hondex). Table 2 summarizes the river width and depth throughout the study period. The concentrations of chlorophyll- $a$ (chl- $a$ ), total suspended solids (TSS), 5-day biochemical oxygen demand $\left(\mathrm{BOD}_{5}\right)$, total nitrogen $(\mathrm{TN})$, ammonium nitrogen $\left(\mathrm{NH}_{4}{ }^{+}-\mathrm{N}\right)$, nitrite

Table 2 Summary of the physical characteristic of Sibu Laut River pooled from the six samplings in year 2010 and year 2011

\begin{tabular}{|c|c|c|c|c|}
\hline \multirow[t]{2}{*}{ Station } & \multicolumn{2}{|l|}{ Width (m) } & \multicolumn{2}{|l|}{ Depth (m) } \\
\hline & Low tide & High tide & Low tide & High tide \\
\hline 1 & $520.3 \pm 67.0$ & $557.3 \pm 30.9$ & $17.9 \pm 1.5$ & $22.0 \pm 2.8$ \\
\hline 2 & $176.5 \pm 26.3$ & $184.0 \pm 30.7$ & $4.9 \pm 0.9$ & $7.0 \pm 0.6$ \\
\hline 3 & $211.3 \pm 30.3$ & $241.0 \pm 76.5$ & $3.0 \pm 1.2$ & $5.3 \pm 0.9$ \\
\hline 4 & $62.3 \pm 9.6$ & $78.9 \pm 26.2$ & $8.2 \pm 1.7$ & $8.1 \pm 1.5$ \\
\hline 5 & $13.6 \pm 3.6$ & $17.4 \pm 0.4$ & $2.0 \pm 0.5$ & $3.3 \pm 0.5$ \\
\hline 6 & $521.8 \pm 27.3$ & $517.8 \pm 37.9$ & $16.6 \pm 0.7$ & $16.7 \pm 1.6$ \\
\hline 7 & $639.3 \pm 20.6$ & $661.6 \pm 24.9$ & $13.0 \pm 0.6$ & $14.3 \pm 0.9$ \\
\hline 8 & $527.7 \pm 34.1$ & $545.9 \pm 18.9$ & $20.8 \pm 1.4$ & $23.5 \pm 0.8$ \\
\hline 9 & $541.1 \pm 12.4$ & $549.4 \pm 31.1$ & $16.4 \pm 1.2$ & $18.3 \pm 1.7$ \\
\hline 10 & $418.4 \pm 5.5$ & $414.1 \pm 25.2$ & $12.1 \pm 3.4$ & $11.8 \pm 3.5$ \\
\hline 11 & $308.7 \pm 17.8$ & $336.4 \pm 55.4$ & $11.8 \pm 0.6$ & $11.3 \pm 0.9$ \\
\hline 12 & $233.5 \pm 79.1$ & $240.9 \pm 75.8$ & $7.4 \pm 1.9$ & $9.0 \pm 2.7$ \\
\hline 13 & $173.0 \pm 113.5$ & $176.8 \pm 125.3$ & $8.7 \pm 2.6$ & $8.1 \pm 0.6$ \\
\hline
\end{tabular}

nitrogen $\left(\mathrm{NO}_{2}{ }^{-}-\mathrm{N}\right)$, nitrate nitrogen $\left(\mathrm{NO}_{3}{ }^{-}-\mathrm{N}\right)$, organic nitrogen $(\mathrm{Org}-\mathrm{N})$, total phosphorus (TP), inorganic phosphorus (IP), and organic phosphorus (OP) were studied. In the study of total heavy metals and bacteriological water quality, three replicate water samples were also taken from the sub-surface and near-bottom water columns for the determination of TSS, total heavy metals $(\mathrm{Zn}, \mathrm{Cu}, \mathrm{Cd}$, and $\mathrm{Pb}$ ) and fecal coliform (FC) bacteria. All sampling bottles were acid-washed, cleaned and dried before use. Sampling bottles for FC bacteria analysis were pre-sterilized with $70 \% \mathrm{v} / \mathrm{v}$ ethanol before use. Water samples were placed in ice box and transported to the laboratory for immediate analysis (Parsons et al. 1984; APHA 2005).

\section{Analytical techniques}

All analyses were done according to standard procedures for water analysis in triplicate unless otherwise mentioned (Parsons et al. 1984; APHA 2005). Concentrations of chl$a$ were determined from adequate samples filtered through $0.7 \mu \mathrm{m}$ Whatman GF/F filters and extracted for $24 \mathrm{~h}$ using $90 \%$ (v/v) acetone. Five-day biochemical oxygen demand was determined as the difference between initial and 5-day dissolved oxygen content, after incubation of the sample in the dark at $20^{\circ} \mathrm{C}$. Total suspended solids were assayed as the difference between initial and final weight of the $0.7 \mu \mathrm{m}$ Whatman GF/F filter paper, after filtration of an adequate sample volume and drying at $105{ }^{\circ} \mathrm{C}$.

The filtered water samples were then used to determine nitrogen and phosphorus concentrations. Inorganic phosphorus was determined by the colorimetric ascorbic acid method while TP was determined as IP after potassium persulfate digestion of samples. Organic phosphorus was calculated as the difference between TP and IP. Ammonium nitrogen and $\mathrm{NO}_{2}{ }^{-}-\mathrm{N}$ were determined by phenate method and colorimetric diazotization method, respectively. Nitrate nitrogen was determined by the ultraviolet spectrophotometric method while $\mathrm{TN}$ was determined as $\mathrm{NO}_{3}{ }^{-}-\mathrm{N}$ after potassium persulfate digestion of the sample. Organic nitrogen was calculated as the difference between $\mathrm{TN}$ and inorganic nitrogen $\left(\mathrm{NH}_{4}{ }^{+}-\mathrm{N}, \mathrm{NO}_{2}{ }^{-} \mathrm{N}\right.$, and $\mathrm{NO}_{3}{ }^{-}$ $\mathrm{N})$. A five-point calibration curve was constructed for each element. Blank and standard solutions were treated in a similar way as sample.

The unfiltered water samples, acidified to $\mathrm{pH}<2$ using ultrapure nitric acid (Merck) were used to determine total heavy metals $(\mathrm{Zn}, \mathrm{Pb}, \mathrm{Cu}$, and $\mathrm{Cd})$ concentrations. Total heavy metals were determined by Flame Atomic Absorption spectrophotometer (iCE 3000 Series AA, Thermo Fisher Scientific) after nitric acid digestion of samples. A three-point calibration curve was constructed for each element. Blank and standard solutions were treated in a similar way as sample. The detection limits for $\mathrm{Zn}, \mathrm{Pb}, \mathrm{Cu}$, 
and $\mathrm{Cd}$ are $0.0033,0.013,0.0045$, and $0.0028 \mathrm{mg} \mathrm{l}^{-1}$, respectively.

A membrane filtration method was used to enumerate FC bacteria as colony-forming unit per $100 \mathrm{ml}$ of sample, $\mathrm{cfu} / 100 \mathrm{ml}$. Duplicate water samples were filtered through a $0.45 \mu \mathrm{m}$ Advantec mixed cellulose ester membrane. Filters were then placed on the m-FC agar (Merck) without rosolic acids. Fecal coliform counts were performed as the number of blue colonies developed on $\mathrm{m}-\mathrm{FC}$ agar plate after $24 \mathrm{~h}$ incubation at $44.5^{\circ} \mathrm{C}$.

\section{Statistical analysis}

Hierarchical cluster analysis, HCA was used to investigate the grouping of the sampling stations along the Sibu Laut River and its tributaries. Ward's method using squared Euclidean distances as a measure of similarity was used. The dendrogram was used to interpret the result of the cluster analysis. Principal component analysis (PCA) was conducted to characterize the loadings of all physicochemical parameters for each of the PCs which were obtained. The PCA was carried out with factors having eigenvectors higher than one (Kaiser criterion). The quality of data for PCA analysis was confirmed with Kaiser-Meyer-Olkin (KMO) measure of sampling adequacy test. The rotation of PCs was made by varimax-normalized algorithm. All the statistical analyses were carried out by the Statistical Software for Social Sciences (SPSS Version 19.0, SPSS Inc. 1995).

\section{Results and discussion}

\section{General environmental variables}

Figure 3 summarizes the general environmental parameters along the Sibu Laut River and tributaries. All thirteen stations along Sibu Laut River and tributaries were determined to be tidally influenced based on the observed salinity values. Salinity was more than $20 \mathrm{ppt}$ even at the most upstream of the river in the present study. Salinity can reach up to $33 \mathrm{ppt}$ at stations near river mouth. Salinity gradient was evident along the river while near-bottom waters were more saline than the sub-surface waters, resulting in weak horizontal and vertical stratification. The mean upstream to downstream salinity difference measured was around 2-3 ppt while the mean sub-surface to nearbottom salinity difference measured was approximately 2 ppt. Malaysia is a tropic country where the temperature is uniform throughout the year (Malaysian Meteorological Department 2012). The temperature was relatively consistent $\left(\approx 29.9{ }^{\circ} \mathrm{C}\right)$ along the river throughout the study periods. Generally, near-bottom waters were slightly cooler than the sub-surface waters, resulting in weak vertical stratification. This is probably attributable to the solar heating of sub-surface waters (Jones et al. 2008). The $\mathrm{pH}$ of the Sibu Laut River was well within range, which near to 7.8 on average. The $\mathrm{pH}$ value was increased towards downstream with the lowest $\mathrm{pH}$ value of 7.0 at the most upstream sites and up to $\mathrm{pH}$ value of 8.9 at the downstream. Near-bottom waters were generally more alkaline than the sub-surface waters. The $\mathrm{pH}$ value was mainly influenced by tides as $\mathrm{pH}$ was higher during high tide. It is known that DO concentrations above $5 \mathrm{mg}^{-1}$ are rarely harmful to aquatic life, whereas concentrations below $2 \mathrm{mg}^{-1}$ are almost always detrimental and are considered a hypoxia threshold (Diaz and Rosenberg 1995). In sub-surface water samples collected in the present study, $62 \%(n=52)$ showed DO concentrations more than $5 \mathrm{mg} \mathrm{l}^{-1}$ while $71 \%$ $(n=52)$ of near-bottom water samples contained more than $5 \mathrm{mg} \mathrm{l}^{-1}$ of the DO. Dissolved oxygen was generally well aerated along the river. However, lower concentration of DO was observed at station 2 in Loba Kilong River and stations 3-5 along Selang Sibu River in low tide condition.

Total suspended solids and turbidity values were steadily increased from the upstream to downstream (Fig. 4). Besides the clear gradient along the river, TDS and turbidity in near-bottom water column were higher than the sub-surface water, most apparent at the downstream and the middle of the river. Total suspended solids and turbidity were also higher during low tide and the variations were larger at downstream and the middle of the main river but smaller at the upstream. Transparency was relatively high in the Sibu Laut River with the lowest transparency observed at station $5(0.56 \mathrm{~m})$ during low tide. The highest averaged transparency was observed at station $7(>2 \mathrm{~m})$. Transparency was higher during high tide at all stations and the variation was most apparent in the middle of the river and upstream. TDS and conductivity exhibited a similar increment trend towards downstream. The lowest value of TDS and conductivity was observed at station 5 during low tide and at station 4 during high tide. Generally, TDS and conductivity were higher during high tide and in nearbottom water column at all stations. TDS and conductivity concentrations are associated with ocean influence and surface water runoff from the shrimp farm effluent. As salinity increases, TDS and conductivity also increase. Shin et al. (2012) demonstrated similar distribution of TDS but the authors attributed the low TDS concentration at upstream to surface water runoff and eliminated the possibility of ocean influence as their sampling was conducted at low tide.

\section{Chlorophyll- $a(\operatorname{chl}-a)$}

Chlorophyll- $a$ content of sub-surface waters samples collected in the present study ranged from $0.207 \pm 0.095$ to 



Fig. 3 Hydrological parameters of a salinity (ppt), b temperature $\left({ }^{\circ} \mathrm{C}\right), \mathbf{c} \mathrm{DO}\left(\mathrm{mg}^{-1}\right), \mathbf{d ~ p H}$, and e conductivity $\left(\mathrm{mS} \mathrm{cm}^{-1}\right)$ at $13 \mathrm{sampling}$ stations along Sibu Laut River and tributaries

$6.144 \pm 1.367 \mathrm{mg} \mathrm{m}^{-3}$, with $50 \%$ of the samples measured $<1 \mathrm{mg} \mathrm{m}^{-3}, 42.3 \%$ of the samples measured between 1 and $3 \mathrm{mg} \mathrm{m}^{-3}$, and $7.7 \%$ of the samples measured more than $5 \mathrm{mg} \mathrm{m}^{-3}$ (Fig. 5). Near-bottom chl$a$ ranged from $0.259 \pm 0.097$ to $9.680 \pm 1.900 \mathrm{mg} \mathrm{m}^{-3}$, with $69.2 \%$ of the samples measured $<1 \mathrm{mg} \mathrm{m}^{-3}, 26.9 \%$ of the samples measured between 1 and $3 \mathrm{mg} \mathrm{m}^{-3}$, and $3.9 \%$ of the samples measured more than $5 \mathrm{mg} \mathrm{m}^{-3}$. On average, the distribution of chl- $a$ was generally low at all stations $\left(0.637 \pm 0.117\right.$ to $\left.0.992 \pm 0.487 \mathrm{mg} \mathrm{m}^{-3}\right)$ except station 5 which exhibited a peak of $5.921 \pm$
$3.260 \mathrm{mg} \mathrm{m}^{-3}$. The chl- $a$ density at station 5 was about 9.5 times higher than the other stations during low tide, but only around 4.5 times higher than the other stations during high tide. Nonetheless, the high chl- $a$ concentration rapidly decreased along the Selang Sibu River down to $0.919 \pm 0.379 \mathrm{mg} \mathrm{m}^{-3}$ at the conjunction with Sibu Laut River. The observation was in good agreement with the study of Thomas et al. (2010) and Trott and Alongi (2000). The decrease of the chl- $a$ may be due to the dilution or high grazing rate of zooplankton on phytoplankton as suggested by La Rosa et al. (2002). Chlorophyll- $a$ data in the present 
(a)

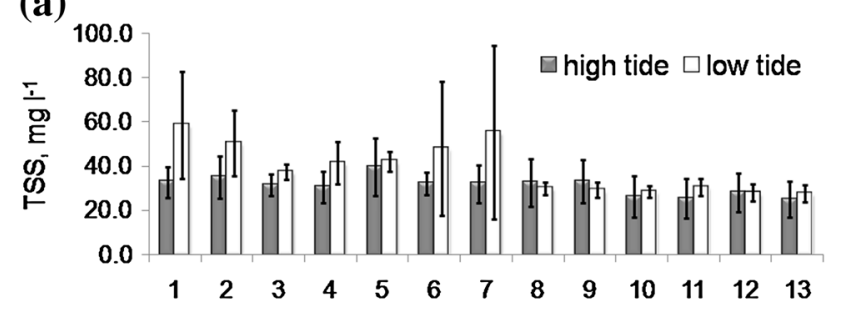

(b)

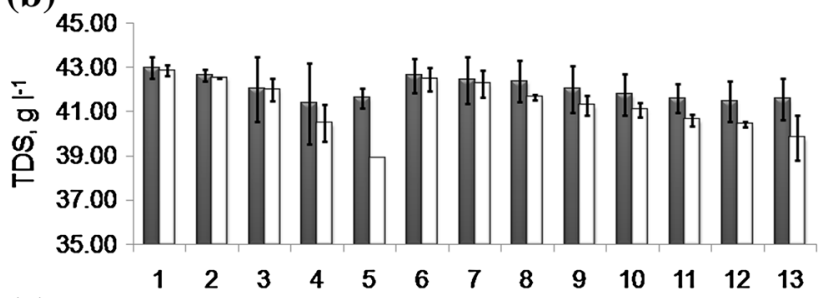

(c)

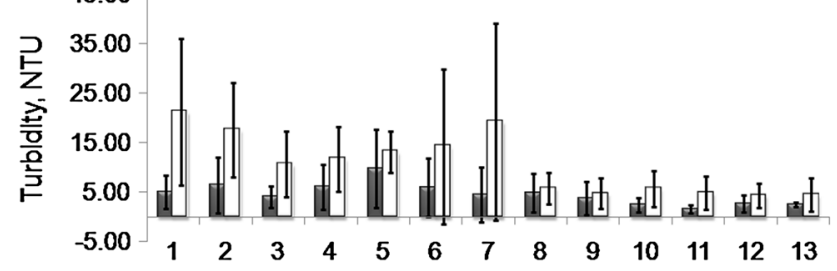

(d) 6.00

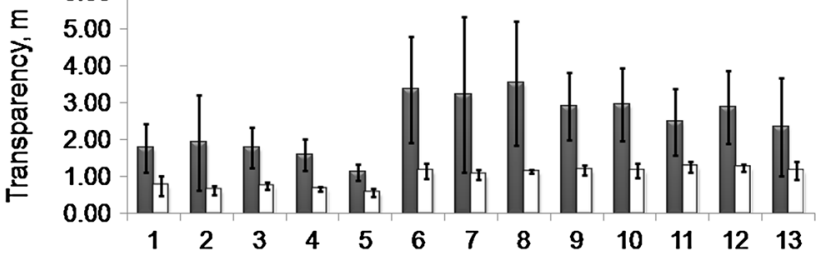

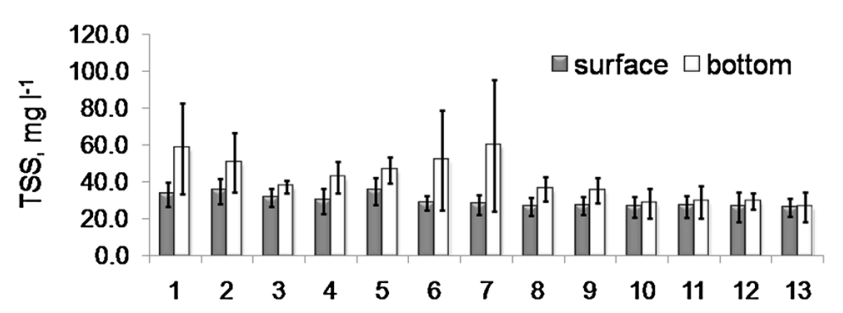
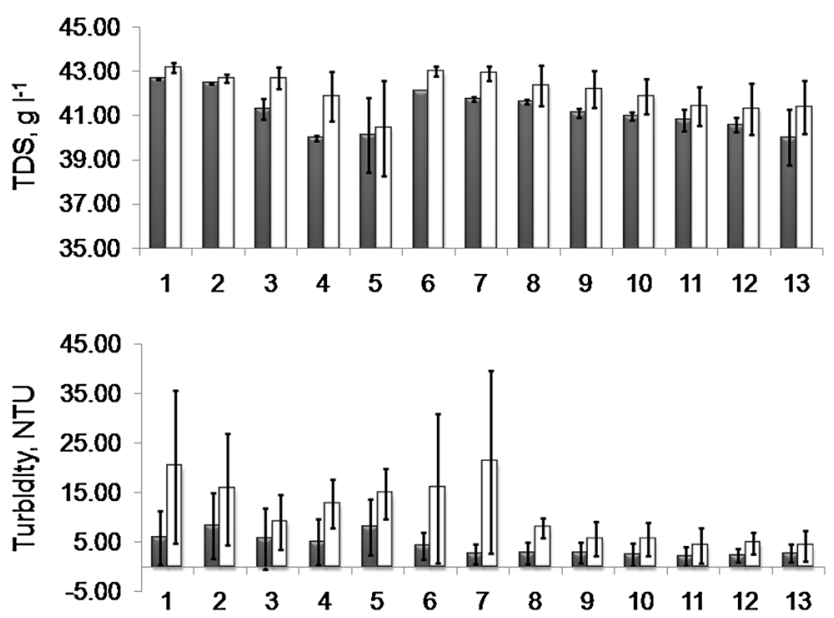

Station

Fig. 4 Mean concentrations of a TSS (mg $\left.\mathrm{m}^{-1}\right)$, b TDS $\left(\mathrm{g} \mathrm{l^{-1 }}\right)$, c turbidity (NTU), and $\mathbf{d}$ transparency (m) at 13 sampling stations along Sibu Laut River and tributaries

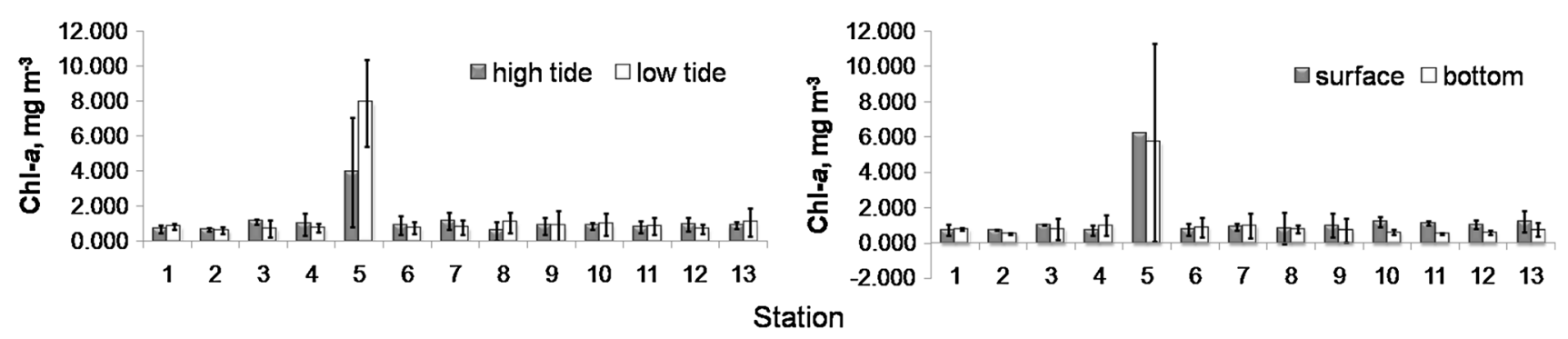

Fig. 5 Mean concentrations of chl-a $\left(\mathrm{mg} \mathrm{m}^{-3}\right)$ at 13 sampling stations along Sibu Laut River and tributaries

study were comparable to the study conducted in Pearl River Estuary, South China as chl- $a$ concentration in the estuary was $0.8-5.6 \mathrm{mg} \mathrm{m}^{-3}$ in ebb tide, and $0.8-7.8 \mathrm{mg} \mathrm{m}^{-3}$ in flood tide (Huang et al. 2003). The present results are also similar with the surface water chl- $a$ concentration $\left(0.28-8.29 \mathrm{mg} \mathrm{m}^{-3}\right)$ observed in the coastal waters of Kalpakkam in the study of Satpathy et al. (2010).
Generally, chl- $a$ level less than $3.4 \mathrm{mg} \mathrm{m}^{-3}$ is indicative of the oligotrophic condition in tidal and fresh waters; ranging from 3.0 to $7.4 \mathrm{mg} \mathrm{m}^{-3}$ is indicative of mesotrophic condition, and chl- $a>6.7 \mathrm{mg} \mathrm{m}^{-3}$ is indicative of eutrophic condition in the Chesapeake Bay (USEPA 2003). Molvaer et al. (1997) stated that for salinity above $20 \mathrm{ppt}$, chl- $a$ concentration $<2 \mathrm{mg} \mathrm{m}^{-3}$ is considered as Class I or 

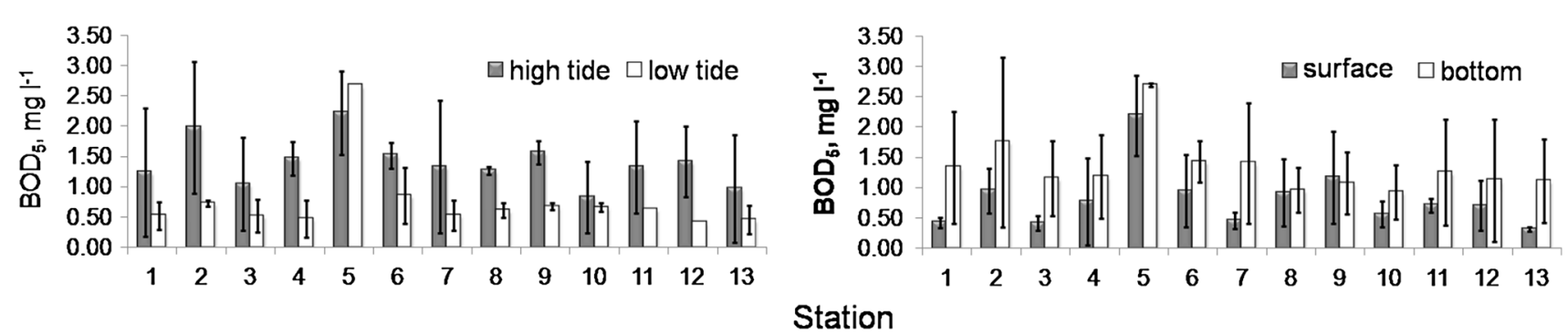

Fig. 6 Mean concentrations of $\mathrm{BOD}_{5}\left(\mathrm{mg}^{-1}\right)$ at 13 sampling stations along Sibu Laut River and tributaries

'very good'. On the other hand, Smith et al. (1999) equated oligotrophic, mesotrophic, eutrophic, and hypertrophic status in marine systems to mean chl- $a$ concentrations $<1 \mathrm{mg} \mathrm{m}^{-3}$, ranging from 1 to $3 \mathrm{mg} \mathrm{m}^{-3}$, ranging from 3 to $5 \mathrm{mg} \mathrm{m}^{-3}$, and more than $5 \mathrm{mg} \mathrm{m}^{-3}$, respectively. When compared to the concentrations of chl- $a$ in Sibu Laut River with the above standard and guideline, the chl$a$ concentration in the Sibu Laut River can be defined as 'very good' as the chl- $a$ value was lower than $2 \mathrm{mg} \mathrm{m}^{-3}$ except station 5 which was characterized as eutrophic or even hypertrophic status. Although chl- $a$ concentration at station 5 showed signs of eutrophication, but the problem was localized as chl- $a$ concentration was decreased rapidly along Selang Sibu River.

Five-day biochemical oxygen demand $\left(\mathrm{BOD}_{5}\right)$

Figure 6 shows that the sub-surface water of the Sibu Laut River and its tributaries was generally low in $\mathrm{BOD}_{5}$, with $69 \%(n=26)$ of the samples contained $<1 \mathrm{mg} \mathrm{l}^{-1}$, $27 \%(n=26)$ of the samples ranged between 1 and $2 \mathrm{mg} \mathrm{l}^{-1}$, and $4 \%(n=26)$ of the samples had $\mathrm{BOD}_{5}$ concentration more than $2 \mathrm{mg} \mathrm{l}^{-1}$. In near-bottom water column, $42.3 \%(n=26)$ showed $\mathrm{BOD}_{5}$ concentration $<1 \mathrm{mg} \mathrm{l}^{-1}, 42.3 \% \quad(n=26)$ ranged between 1 and $2 \mathrm{mg} \mathrm{l}^{-1}$, and the remaining $15.4 \%(n=26)$ of the samples had more than $2 \mathrm{mg} \mathrm{l}^{-1}$. The highest concentration of $\mathrm{BOD}_{5}$ was found at station 5 which in the receiving creek of the wastewater discharged from a shrimp farm. Besides, stations 2, 6, and 9 also contained higher $\mathrm{BOD}_{5}$ values. The high $\mathrm{BOD}_{5}$ values in those sites indicated that the organic matter being input to the river. Generally, $\mathrm{BOD}_{5}$ was higher in near-bottom $\left(\approx 1.34 \mathrm{mg} \mathrm{l}^{-1}\right)$ water column compared to sub-surface $\left(\approx 0.81 \mathrm{mg} \mathrm{l}^{-1}\right)$; and during high tide $\left(\approx 1.40 \mathrm{mg} \mathrm{l}^{-1}\right)$ compared to low tide $\left(\approx 0.75 \mathrm{mg} \mathrm{l}^{-1}\right)$. The result was in contrast to the study of Yin and Harrison (2007) where the $\mathrm{BOD}_{5}$ was about $1 \mathrm{mg} \mathrm{l}^{-1}$ near the bottom and more than $1.5 \mathrm{mg} \mathrm{l}^{-1}$ at the surface water at Victoria Harbour, respectively. Nevertheless, the authors also showed that bottom $\mathrm{BOD}_{5}$ may be higher as phytoplankton cell sinks to the bottom layer.
Elevated concentrations of $\mathrm{BOD}_{5}$ were found near to shrimp farm, villages and jetty in the present study, yet, the $\mathrm{BOD}_{5}$ concentration was comparatively lower than other studies with sewage and anthropogenic influences. Shin et al. (2012) demonstrated that $\mathrm{BOD}_{5}$ concentration was higher at upriver near combined sewer overflow and sewage treatment plant effluents in the Hackensack River Estuary with an average of $\mathrm{BOD}_{5}$ fluctuated between 3.5 and $12.8 \mathrm{mg} \mathrm{l}^{-1}$. Organic pollution is even more severe in Lower Sebou polluted by Gharb plain wastes with the means $\mathrm{BOD}_{5}$ vary from 19 to $76 \mathrm{mg} \mathrm{l}^{-1}$ (Bennasser et al. 1997). Extremely high $\mathrm{BOD}_{5}$ concentration was also found in Chetumal Bay which registered a mean $\mathrm{BOD}_{5}$ of $32.26 \mathrm{mg} \mathrm{l}^{-1}$ (Ortiz-Hernandez and Saenz-Morales 1999). Similar results with the present study was found in the study of Song et al. (2011) who reported that the $\mathrm{BOD}_{5}$ concentration ranged from 0.807 to $7.557 \mathrm{mg}^{-1}$ near the industrial and urban area in a tributary of the Pearl Estuary-Beijiang River. In Malaysia, the mean values of $\mathrm{BOD}_{5}$ were in the range of 0.26 to $2.95 \mathrm{mg} \mathrm{l}^{-1}$ in the Chini Lake (Hamzah and Hattasrul 2008) and from 2.36 to $15.37 \mathrm{mg} \mathrm{l}^{-1}$ in Langat River from 1995 to 2002 (Juahir et al. 2011).

Dissolved phosphorus

Figure 7 shows the distribution of phosphorus along Sibu Laut River and tributaries. The highest TP concentration was observed at station 5 in the Selang Sibu River, which steadily reduced along the river from $0.047 \pm 0.041$ to $0.010 \pm 0.009 \mathrm{mg}^{-1}$ at station 3. Station 2 which was located in Loba Kilong River also showed elevated phosphorus concentration with an average of $0.022 \pm$ $0.009 \mathrm{mg} \mathrm{l}^{-1}$. Total phosphorus was lower in the middle and upstream sites, ranging from $0.007 \pm 0.003$ to $0.011 \pm 0.006 \mathrm{mg} \mathrm{l}^{-1}$ except stations 6,9 , and 10 $\left(0.014 \pm 0.012\right.$ to $\left.0.018 \pm 0.013 \mathrm{mg} \mathrm{l}^{-1}\right)$. Organic phosphorus constituted the major proportion of the composition of phosphorus on the river basin, contributing 57.5-88.4\% of the TP. The distribution of OP followed the trend of TP where higher concentrations of OP were found at stations 2,4 , and 5. Inorganic phosphorus was generally low at all 
(a)


(b)
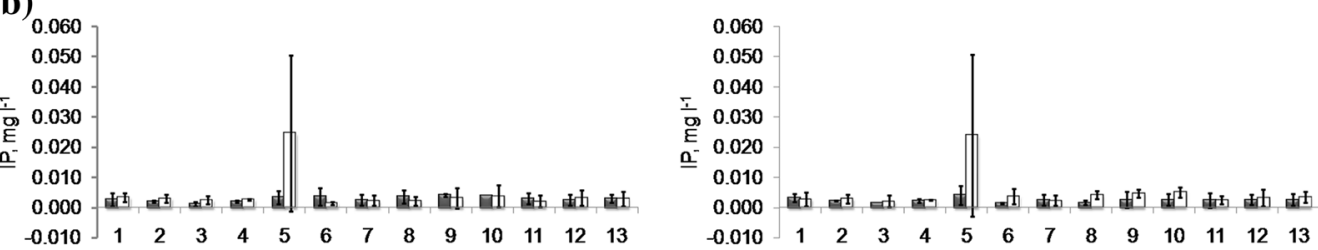

(c)
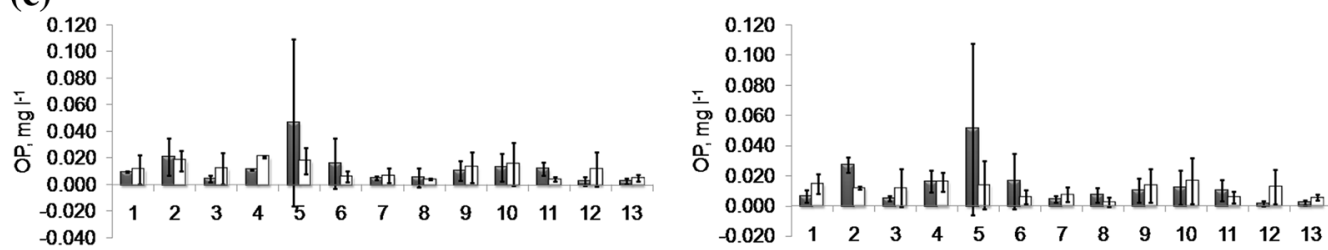

(d)
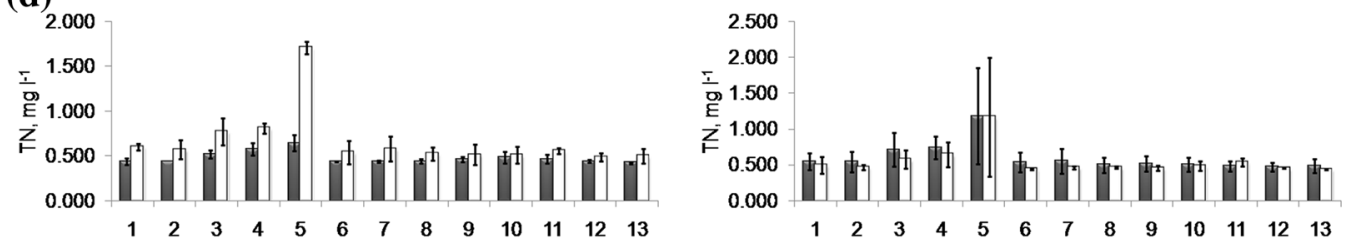

(e) 0.030

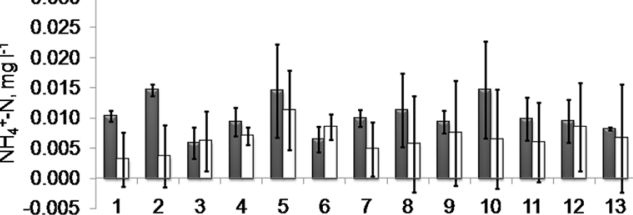

0.030

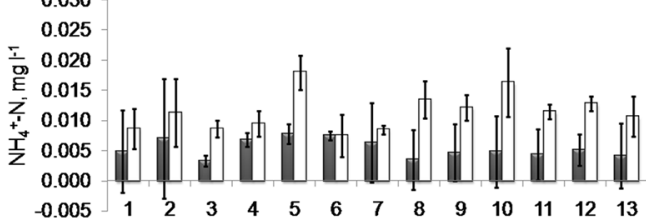

(f) 0.800
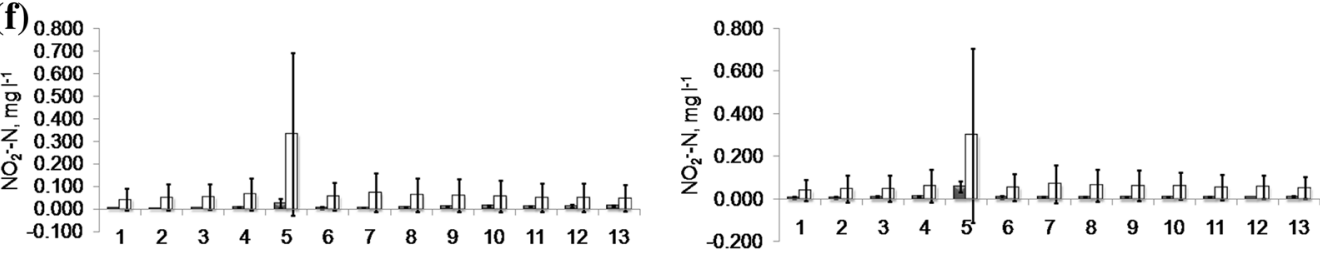

(g) ${ }_{1.400}$
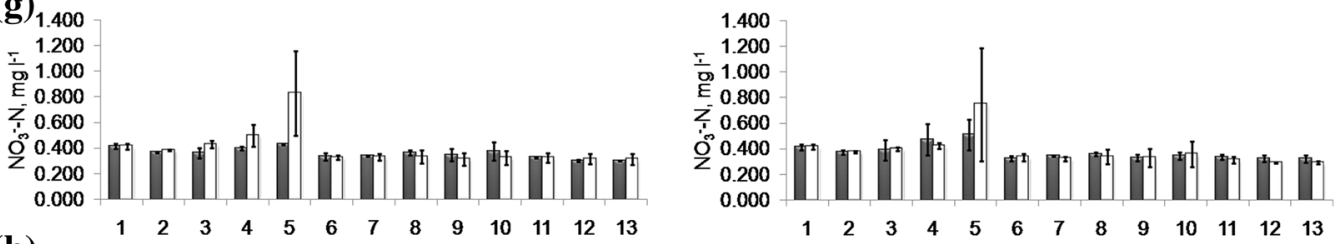

(h)
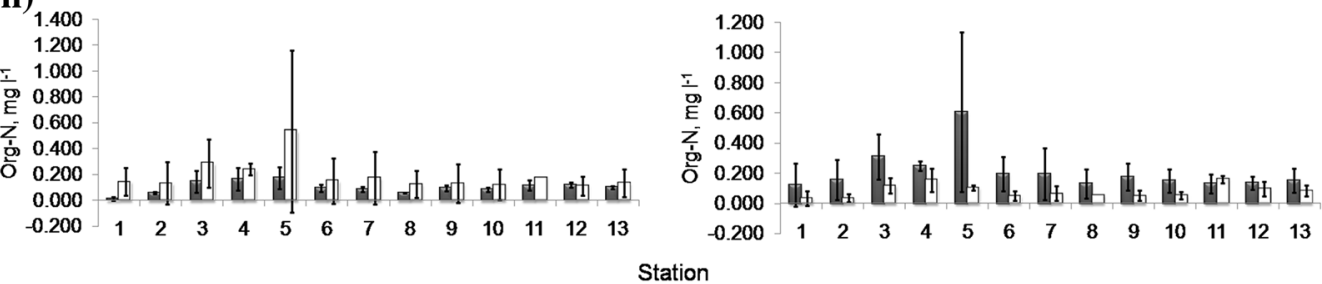

Fig. 7 Mean concentrations $\left(\mathrm{mg}^{-1}\right)$ of a TP, $\mathbf{b} \mathrm{IP}, \mathbf{c} \mathrm{OP}, \mathbf{d} \mathrm{TN}, \mathbf{e ~} \mathrm{NH}_{4}{ }^{+}-\mathrm{N}, \mathbf{f ~ N O}{ }^{-}{ }^{-} \mathrm{N}, \mathbf{g ~ N O}_{3}{ }^{-}-\mathrm{N}$, and $\mathbf{h}$ Org- $\mathrm{N}$ at 13 sampling stations along Sibu Laut River and tributaries 
stations, contributing only $11.6-42.5 \%$ of the TP. Nevertheless, station 5 which was near to the discharge point of the shrimp farm exhibited a peak of $0.014 \pm 0.019 \mathrm{mg}$ IP $1^{-1}$.

The Sibu Laut River contained extremely low concentrations of IP with an average of $0.003 \mathrm{mg} \mathrm{l}^{-1}$. The result was comparable to the study of Troussellier et al. (2004) who reported the orthophosphate concentration was $0.03 \mu \mathrm{mol} \mathrm{l}^{-1}\left(\approx 0.001 \mathrm{mg} \mathrm{l}^{-1}\right)$ in the Senegal River Estuary. On the other hand, the concentration of IP in the present study was considerably lower than a Pearl River estuarine system of Hong Kong (Huang et al. 2003) and Kalpakkam Estuary in India (Satpathy et al. 2010) with an IP range of $0.007-0.017 \mathrm{mg} \mathrm{l}^{-1}$ and $0.05-1.96 \mu \mathrm{mol} \mathrm{l}^{-1}$ $\left(\approx 0.002-0.061 \mathrm{mg} \mathrm{l}^{-1}\right)$, respectively.

Averages of phosphorus concentration exhibited horizontal gradients, which were most pronounced near shrimp farm discharge point on Selang Sibu River. The phosphorus concentrations decreased with distance from the shrimp farm discharge point from $0.047 \pm 0.041$ to $0.010 \pm$ $0.009 \mathrm{mg} \mathrm{l}^{-1}, 0.014 \pm 0.019$ to $0.002 \pm 0.001 \mathrm{mg} \mathrm{l}^{-1}$, and $0.033 \pm 0.040$ to $0.009 \pm 0.008 \mathrm{mg} \mathrm{l}^{-1}$ for TP, IP, and OP, respectively. This was in good agreement with results from Wu et al. (1994) where the impacts of marine fish farming activities on water quality were localized and did not appear to extend beyond a distance of 1-1.5 km from the fish rafts. Trott and Alongi (2000) suggested that the shrimp farm effluent was dissipated by tides and assimilated by the estuarine food web. Tidal mangrove estuaries have some capacity to process the intermittent inputs of pond-derived nutrients at least over short spatial and temporal scales. Thomas et al. (2010) and Ribeiro and Kjerfve (2002) also reported similar water quality improvement with distance. The dilution factor along Selang Sibu River was varied among phosphorus species. Inorganic phosphorus was dissipated faster than TP and OP. The dilution factor for IP $(\approx 7)$ was relatively higher than TP $(\approx 2.5)$ and OP $(\approx 2.1)$ from station 5 to station 4 . Inorganic phosphorus was rapidly assimilated within the $1 \mathrm{~km}$ distance from station 5 to station 4; but no further decrement was observed from station 4 to station 3. Total phosphorus and OP were continued to decrease from station 4 to station 3 with a lower rate approximately $1.8-1.9$ times. It is hypothesized that though phytoplankton is able to assimilate various types of phosphorus, but is preferred IP rather than OP (Cotner and Wetzel 1992), hence IP was decreased faster than OP.

In addition to phosphorus enrichment associated with shrimp farm effluents, Sibu Laut River is also susceptible to the domestic sewage effluent. This can be seen from the results that measurements of phosphorus revealed considerable enrichment at station 2 besides of station 5 . In the present study, sub-surface TP and OP at station 2 were 2.9 times and 3.4 times higher than the other stations along Sibu Laut River; whereas IP concentration was similar to the other stations. The elevated phosphorus concentrations were confined to sub-surface water as near-bottom phosphorus at station 2 was similar or even lower than other stations. Since station 2 is near to the Sibu Laut Village, the high mean phosphorus concentration indicated that wastewater discharged from the village was likely to contribute to the high phosphorus observed as phosphorus is an important component of domestic detergents. Ling et al. (2010a) reported high loading of reactive phosphorus into rivers in Kuching, Sarawak, from household wastewater, especially low income residential area which are attributable to more usage of phosphorus detergent. Besides, as station 2 was in the Loba Kilong River near the downstream, the intrusion of the seawater also helps to dilute the phosphorus concentration in the near-bottom water column.

Higher concentrations of phosphorus in the sub-surface water of station 2 and station 5 revealed that the sub-surface phosphorus runoff from shrimp farm and domestic sewage effluent is entering the area. Nevertheless, higher near-bottom IP concentration was observed at station 5 . Sedimentation and re-suspension may play a major role in the distribution of phosphorus in the near-bottom water column (Pomeroy et al. 1965). The high load of phosphorus from a shrimp farm effluent may sorb to particulate matter and settle on the sediment in the intake creek of shrimp farm effluents (Sondergaard et al. 2001). There are no noticeable trends of the vertical profiles of phosphorus at other stations.

A mean TP concentration $<0.010 \mathrm{mg}^{-1}$ is characterized as oligotrophic status, ranging from 0.010 to $0.030 \mathrm{mg}^{-1}$ is mesotrophic status, ranging from 0.030 to $0.040 \mathrm{mg} \mathrm{l}^{-1}$ is eutrophic status, and more than $0.040 \mathrm{mg} \mathrm{l}^{-1}$ is hypertrophic status (Smith et al. 1999). Total phosphorus concentration is low in the Sibu Laut River as $48 \%$ of the samples $(n=52)$ contained $<0.010 \mathrm{mg} \mathrm{l}^{-1}$ and $42 \%$ of the samples $(n=52)$ ranged from 0.010 to $0.030 \mathrm{mg} \mathrm{l}^{-1}$. There are only 6 and $4 \%$ of the water samples characterized as eutrophic and hypertrophic status. On the other hand, IP in all the samples collected in this study complied with the limit of $75 \mu \mathrm{gO}_{4} \mathrm{l}^{-1}\left(\approx 0.024 \mathrm{mg} \mathrm{l}^{-1}\right)$ according to the Malaysia Marine Water Quality Criteria and Standard except a water sample collected from station 5 during low tide $\left(0.043 \pm 0.001 \mathrm{mg} \mathrm{l}^{-1}\right)$.

\section{Dissolved nitrogen}

The distribution of nitrogen was relatively consistent along Sibu Laut River and tributaries, ranging from $0.466 \pm 0.063$ to $0.697 \pm 0.144 \mathrm{mg} \mathrm{l}^{-1}$ except station 5 which exhibited a peak of $1.177 \pm 0.618 \mathrm{mg} \mathrm{l}^{-1}$. In addition, concentrations of $\mathrm{NH}_{4}{ }^{+}-\mathrm{N}, \mathrm{NO}_{2}{ }^{-}-\mathrm{N}, \mathrm{NO}_{3}{ }^{-}-\mathrm{N}$, 
and Org-N were also the highest at station 5 and steadily reduced along Selang Sibu River. Inorganic nitrogen (InOrg-N) constituted the major proportion of the composition of nitrogen in the river basin, contributing $75.6 \%$ of $\mathrm{TN}$. Nitrate nitrogen was the major composition among the InOrg-N, contributing about $67.0 \%$, followed by $\mathrm{NO}_{2}{ }^{-} \mathrm{N}$ (7.1\%), and $\mathrm{NH}_{4}{ }^{+}-\mathrm{N}(1.5 \%)$. Ammonium nitrogen was low in the study area, ranging from $0.006 \pm 0.003$ to $0.013 \pm 0.006 \mathrm{mg} \mathrm{l}^{-1}$. Nitrite nitrogen was relatively consistent along the river, ranging from $0.024 \pm 0.035$ to $0.040 \pm 0.062 \mathrm{mg} \mathrm{l}^{-1}$ when excluding station 5 $\left(0.179 \pm 0.273 \mathrm{mg} \mathrm{l}^{-1}\right)$. Concentration of $\mathrm{NO}_{3}{ }^{-}-\mathrm{N}$ was found higher at the river mouth $\left(0.415 \pm 0.018 \mathrm{mg} \mathrm{l}^{-1}\right)$ while Org-N exhibited a different trend as concentrations were higher at the upper reaches of the river and lower at downstream sites.

The present study showed that the influence of the shrimp farm was reduced along Selang Sibu Laut as indicated by the decreasing nitrogen concentrations as similar to phosphorus distribution described previously. The nitrogen concentrations decreased with distance from the shrimp farm discharge point from $1.177 \pm 0.618$ to $0.647 \pm 0.174 \mathrm{mg}^{-1}$ of $\mathrm{TN}$, $0.013 \pm 0.006$ to $0.006 \pm 0.003 \mathrm{mg} \mathrm{l}^{-1}$ of $\mathrm{NH}_{4}{ }^{+}-\mathrm{N}$, $0.179 \pm 0.273$ to $0.030 \pm 0.043 \mathrm{mg} \mathrm{l}^{-1}$ of $\mathrm{NO}_{2}{ }^{-}-\mathrm{N}$, $0.630 \pm 0.298$ to $0.396 \pm 0.047 \mathrm{mg} \mathrm{l}^{-1}$ of $\mathrm{NO}_{3}{ }^{-}-\mathrm{N}$, and $0.355 \pm 0.421$ to $0.216 \pm 0.143 \mathrm{mg} \mathrm{l}^{-1}$ of Org-N, respectively. The dilution factor from station 5 to station 4 was relatively similar among $\mathrm{TN}, \mathrm{NH}_{4}{ }^{+}-\mathrm{N}, \mathrm{NO}_{3}{ }^{-}-\mathrm{N}$, and Org-N, ranging from 1.40 to 1.76 times. Nitrite nitrogen was the fastest dissipated nitrogen species with a dilution factor of 4.84 times. A dilution factor of about 40 times for nitrogen components was reported from the head of channels to the Santos Bay (Braga et al. 2000). The authors attributed the dilution to assimilation, physical mixture and other removal processes that present in the system. Nitrogen was rapidly dissipated within the $1 \mathrm{~km}$ distance from station 5 to station 4; but no further apparent decrement was observed from station 4 to station 3 as the nitrogen was decreased at an extremely slow rate. It is hypothesized that $\mathrm{NO}_{2}{ }^{-} \mathrm{N}$ as an unstable intermediate form of $\mathrm{NH}_{4}{ }^{+} \mathrm{N}$ and $\mathrm{NO}_{3}{ }^{-}-\mathrm{N}$ will tend to reduce to $\mathrm{NH}_{4}{ }^{+}-\mathrm{N}$ or oxidize to $\mathrm{NO}_{3}{ }^{-}-\mathrm{N}$ forms, hence the dilution factor of $\mathrm{NO}_{2}{ }^{-}-\mathrm{N}$ was the highest. Organic nitrogen was the second fastest nitrogen species that dissipated other than $\mathrm{NO}_{2}{ }^{-}-\mathrm{N}$. Seitzinger and Sanders (1997) suggested that in estuaries with residence times on the order of weeks to months, such as Delaware Bay, river inputs of the biologically available portion of dissolved organic nitrogen (DON) are first utilized within the estuary. In contrast, in estuaries with residence times of less than a week, such as New York Bay, a portion of the biologically available DON may be utilized first within the estuary, with the remainder exported and utilized in continental shelf waters.
There was noticeable variation in the nitrogen concentration explained by differences in tidal stage. In general, the concentrations of $\mathrm{TN}, \mathrm{NO}_{2}{ }^{-}-\mathrm{N}$, and Org- $\mathrm{N}$ were found higher during low tide in most observations. Higher $\mathrm{NO}_{3}{ }^{-}$$\mathrm{N}$ concentration was also observed at station 3 to station 5 on Selang Sibu River during low tide. A similar observation was reported by Ribeiro and Kjerfve (2002) where the Bay water quality was best at high tide at the time of maximum tidal dilution. On the other hand, $\mathrm{NH}_{4}{ }^{+} \mathrm{N}$ exhibited different trends where higher concentration was observed during high tide at most of the stations. Marginally high sub-surface TN and Org-N concentrations were noticed at all stations except station 11 . The largest variety of sub-surface and near-bottom Org- $\mathrm{N}$ was observed at station 5 indicated that the sub-surface water in the intake creek is influenced by the shrimp farm effluents rich in Org-N. Contrary to TN and Org-N concentrations, nearbottom $\mathrm{NH}_{4}{ }^{+}-\mathrm{N}$ and $\mathrm{NO}_{2}{ }^{-}-\mathrm{N}$ concentrations were higher than sub-surface water. Sub-surface and near-bottom concentrations of $\mathrm{NO}_{3}{ }^{-}-\mathrm{N}$ were relatively similar, except station 5 where near-bottom $\mathrm{NO}_{3}{ }^{-}-\mathrm{N}$ was higher than the sub-surface. Accumulation of high amounts of nutrients in sediments was evident from the high concentration of the overlying water discharged from a shrimp farm (Shahidul et al. 2004). The presence of higher nitrogen in near-bottom water samples could be due to either re-suspension of fine sediments by currents or to the disturbance of the bottom during sampling (Balls et al. 1994).

Smith et al. (1999) equated oligotrophic, mesotrophic, eutrophic, and hypertrophic status in marine systems to mean TN concentrations $<0.26 \mathrm{mg} \mathrm{l}^{-1}$, ranging from 0.260 to $0.350 \mathrm{mg} \mathrm{l}^{-1}$, ranging from 0.350 to $0.400 \mathrm{mg} \mathrm{l}^{-1}$, and more than $0.400 \mathrm{mg} \mathrm{l}^{-1}$, respectively. Sibu Laut River and its tributaries are characterized as hypertrophic status as the whole system contained more than $0.400 \mathrm{mg} \mathrm{TN}{ }^{-1}$. Comparisons of the results of the present study with the Malaysia Marine Water Quality Criteria and Standard (Department of Environment 2010) indicated that $\mathrm{NH}_{4}{ }^{+} \mathrm{N}$ in Sibu Laut River complied with the guideline value set by the Department of Environment, Malaysia. All the $\mathrm{NH}_{4}{ }^{+}-\mathrm{N}$ concentration observed in the present study was lower than $70 \mu \mathrm{g}^{-1}$ of un-ionized ammonia $\left(\approx 0.054 \mathrm{mg} \mathrm{l}^{-1}\right.$ of un-ionized ammonia nitrogen). Nitrite nitrogen complied with the guideline value of $55 \mu \mathrm{g} \mathrm{NO}_{2} 1^{-1}\left(\approx 0.017 \mathrm{mg} \mathrm{l}^{-1}\right)$ at most of the stations. However, near-bottom $\mathrm{NO}_{2}^{-}-\mathrm{N}$ concentration in the Sibu Laut River exceeded the guideline value during low tide with $\mathrm{NO}_{2}{ }^{-}-\mathrm{N}$ concentration ranged from 0.077 to $0.587 \mathrm{mg} \mathrm{l}^{-1}$. On the other hand, $\mathrm{NO}_{2}{ }^{-}-\mathrm{N}$ concentrations on three out of four water samples at station 5 were violated the guideline value. Nitrate nitrogen violated the guideline value of $60 \mu \mathrm{g} \mathrm{NO}_{3} \mathrm{l}^{-1}\left(\approx 0.014 \mathrm{mg} \mathrm{l}^{-1}\right)$ at all stations throughout the study periods. Nitrate is 
thermodynamically the most stable form of InOrg-N in well-oxygenated waters. The reference level of $0.014 \mathrm{mg} \mathrm{l}^{-1}$ for nitrate may be too low because nitrate is relatively non-toxic to aquatic organisms (Wickins 1976; Rubin and Elmaraghy 1977). No formal water quality criteria and standard exist for nitrate in estuarine waters. The Canadian Council of Ministers of the Environment (2003) has recommended nitrate concentration ranging 2.9-3.6 $\mathrm{mg} \mathrm{l}^{-1}$ to protect freshwater and marine life; whereas Camargo et al. (2005) proposed a maximum level of $2 \mathrm{mg} \mathrm{l}^{-1}$ for the protection of sensitive aquatic animals. What is more, the nitrate concentration for USA federal maximum level for drinking water is $10 \mathrm{mg}^{-1}$ (USEPA 2009). Accordingly, nitrate concentrations in the Sibu Laut River are still under the recommended value as nitrate concentration was below $2 \mathrm{mg}^{-1}$ even at station 5 .

Total heavy metals $(\mathrm{Zn}, \mathrm{Pb}, \mathrm{Cu}$, and $\mathrm{Cd})$

Figure 8 shows the distributions of total $\mathrm{Zn}, \mathrm{Pb}$, and $\mathrm{Cu}$ along Sibu Laut River and tributaries. The distribution of total $\mathrm{Cd}$ was not shown as the concentration of total $\mathrm{Cd}$ was below the detection limit at all stations throughout the study period. Lead appears to be the most abundant metal measured in the present study. The distribution of total $\mathrm{Pb}$ was relatively consistent along the river and tributaries when the data was pooled from the 13 stations during high and low tides, with an average of $0.0277 \mathrm{mg}^{-1}$. Total $\mathrm{Pb}$ in this study was lower than the values quoted by Shin et al. (2012) in the study of total metal accumulation in the Hackensack River, Northern New Jersey (0.0349-0.2139 $\mathrm{mg} \mathrm{Pb}^{-1}$ ) but was higher than the reported value for Potiguar Basin $\left(\leq 0.002 \mathrm{mg} \mathrm{l}^{-1}\right)$ and Thames Estuary $\left(\leq 0.008 \mathrm{mg} \mathrm{l}^{-1}\right)$ by Lacerda et al. (2013) and Pope and Langston (2011), respectively. Copper is the second most abundant metal in the river and is distributed geochemically in a similar manner to total $\mathrm{Pb}$, with an average of $0.0160 \mathrm{mg} \mathrm{l}^{-1}$. Total $\mathrm{Cu}$ concentration was within the range of Thames Estuaries (0.0097-0.2346 $\mathrm{mg} \mathrm{l}^{-1}$ ) and Hackensack River (0.0102-0.0363 $\left.\mathrm{mg} \mathrm{l}^{-1}\right)$ and higher than the reported values $\left(\approx 0.002 \mathrm{mg} \mathrm{l}^{-1}\right)$ for Potiguar Basin. The concentration of total $\mathrm{Zn}$ was comparatively more fluctuated along Sibu Laut River and tributaries. The lowest concentration of total $\mathrm{Zn}$ was found in downstream $\left(0.0024 \mathrm{mg} \mathrm{l}^{-1}\right)$ while the highest concentration of total $\mathrm{Zn}$ was observed at station $9\left(0.0119 \pm 0.0097 \mathrm{mg} \mathrm{l}^{-1}\right)$. Other than that, total $\mathrm{Zn}$ were relatively consistent on the main river with an average of $0.0079 \mathrm{mg}^{-1}$. Total $\mathrm{Zn}$ was lower than the highest values
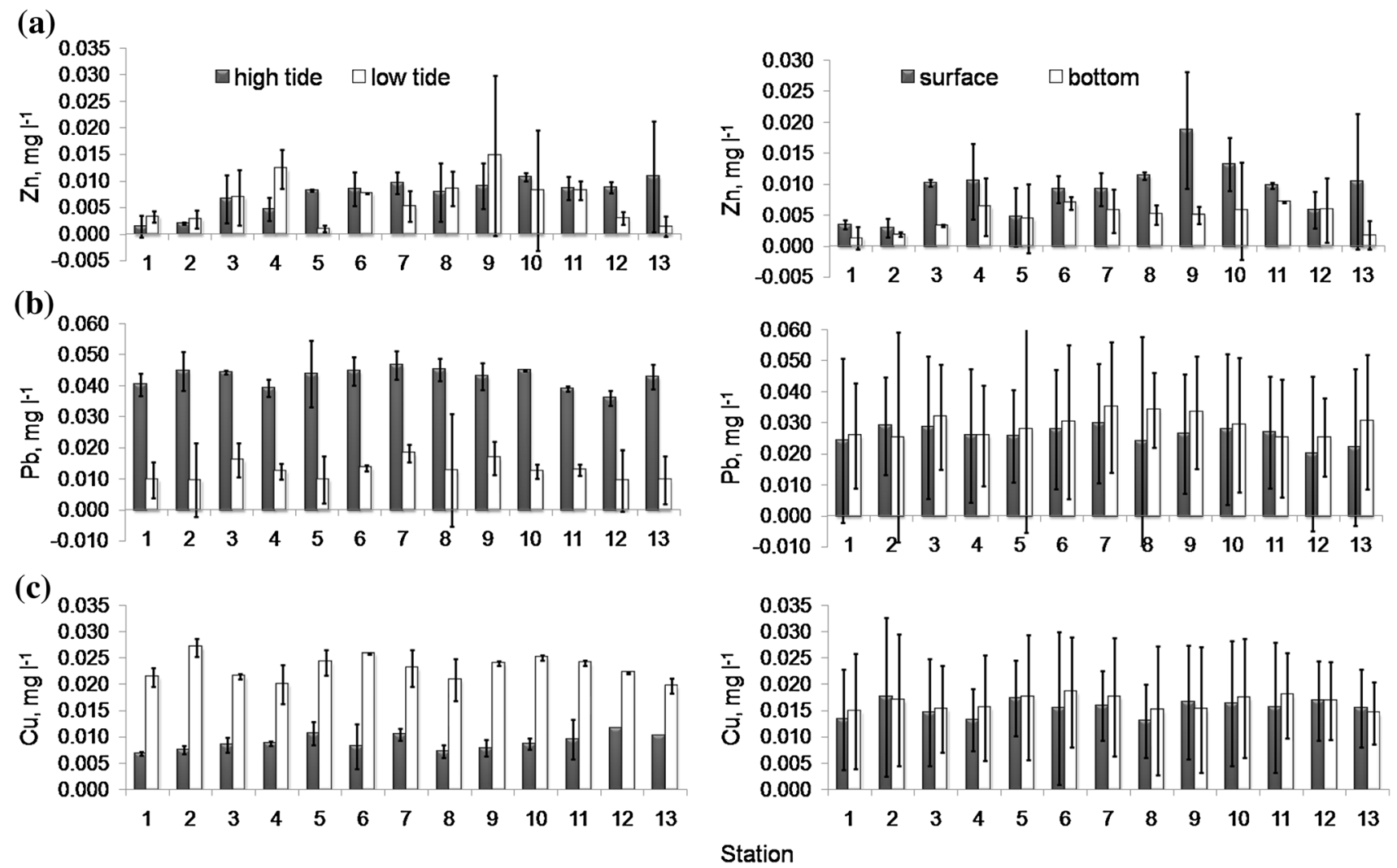

Fig. 8 Mean concentrations $\left(\mathrm{mg} \mathrm{l}^{-1}\right.$ ) of $\mathbf{a} \mathrm{Zn}, \mathbf{b} \mathrm{Pb}$, and $\mathbf{c} \mathrm{Cu}$ at 13 sampling stations along Sibu Laut River and tributaries 

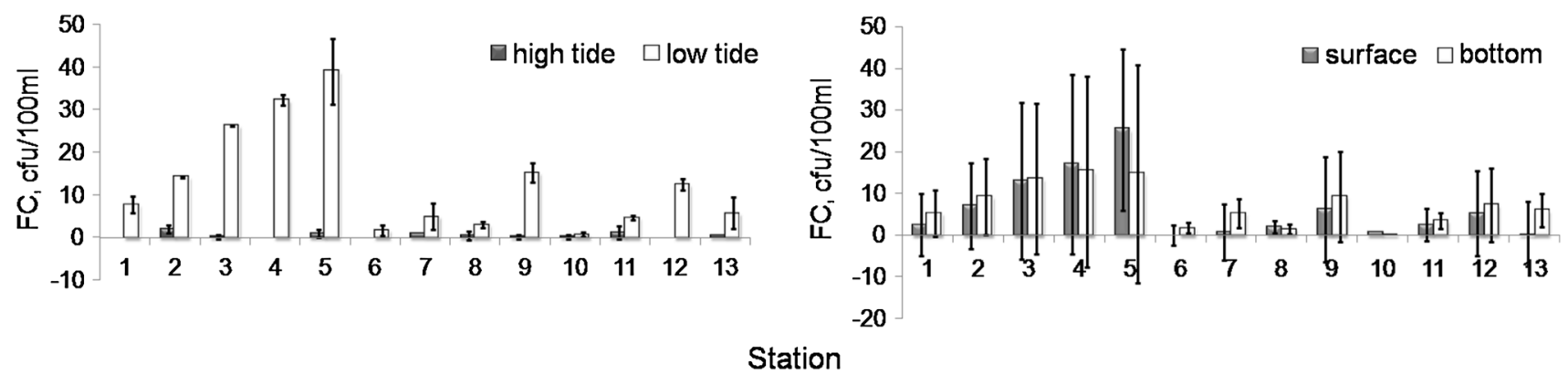

Fig. 9 Mean concentrations of FC (cfu/100 ml) at 13 sampling stations along Sibu Laut River and tributaries

reported in the Hackensack River $\left(0.0312-0.0849 \mathrm{mg} \mathrm{l}^{-1}\right.$ ) and Thames Estuary $\left(0.0330-0.0773 \mathrm{mg} \mathrm{l}^{-1}\right)$. Cadmium was the least metal measured in the present study at which it is below the detection limit at all stations throughout the study periods. Total $\mathrm{Cd}$ concentration is similar with Potiguar Basin, which is also below detection level and is lower than values reported in the Hackensack River (0.0042-0.0328 mg l$\left.{ }^{-1}\right)$. Nduka and Orisakwe (2009) reported high level of Cd on the surface water of Aja-Etan and Ijala $\left(\approx 1.33 \mathrm{mg} \mathrm{l}^{-1}\right)$ while high $\mathrm{Pb}$ was found on the surface water of Ifie-kporo and Ekpan $\left(\approx 0.95 \mathrm{mg} \mathrm{l}^{-1}\right)$.

Total heavy metals in the intake creek of shrimp farm effluent (station 5) were within ambient level with other stations in the Sibu Laut River. The results showed that the shrimp farm effluent had no major impact on heavy metals pollution in the receiving creek. Heavy metals are not major pollutants in shrimp farm effluents. In many cases, the study of heavy metal related to shrimp farm is more concerned on the accumulation of heavy metals in shrimps as it may adversely affect the health of the final consumption user (Amaraneni 2006; Kurun et al. 2007).

The main natural sources of metals into the aquatic system are the weathering of soils and rocks and precipitation; or from anthropogenic activities such as industrial, domestic, and urban sewage runoffs (Rippey 1982; Caccia and Millero 2003; Du Laing et al. 2008; Nduka and Orisakwe 2009; Sundaray et al. 2012). Elevated concentrations of total $\mathrm{Zn}$ were observed at station 9. These concentration peaks may represent events of re-suspension or the presence of $\mathrm{Zn}$-enriched particles as suggested by Lacerda et al. (2013). In contrast, the total metal concentrations of $\mathrm{Cu}$ and $\mathrm{Pb}$ in the river showed no particular trend and this indicated that the source might be diffused. The source of total $\mathrm{Pb}$ on Sibu Laut River could be due to the anthropogenic activities from adjacent villages as domestic sewage discharge and seepage from waste disposal sites could contribute greatly to the $\mathrm{Pb}$ concentration (Simeonov et al. 2003; Fianko et al. 2007). Soil leaching is the main factor that contributes to the $\mathrm{Cu}$ concentration as suggested by Simeonov et al. (2003). Besides, $\mathrm{Cu}$ released from the antifouling paints used on boat hulls could also contribute to the $\mathrm{Cu}$ concentration (Caccia and Millero 2003; Whitall et al. 2010).

Sub-surface $\mathrm{Zn}$ were generally higher than near-bottom water, whereas $\mathrm{Pb}$ and $\mathrm{Cu}$ were not notably different between sub-surface and near-bottom water column. Lourino-Cabana et al. (2011) attributed the highly variable of Zn concentration in the Deûle River to re-suspension of polluted sediment and biological activities. In contrary, metal concentrations in surface and bottom waters in Potiguar Basin, Northeastern Brazil under the influence of the Guamare outfalls showed no difference, suggesting completing mixing of the water column in this relatively $(<20 \mathrm{~m}$ ) shallow waters (Lacerda et al. 2013). On the other hand, the present study showed that $\mathrm{Zn}$ and $\mathrm{Pb}$ were higher during high tide while $\mathrm{Cu}$ was considerably higher during low tide. Hatje (2003) demonstrated that concentrations of particulate trace metals, in general, tended to be higher at flood than ebb tide in Port Jackson Estuary, Australia. The higher concentration of $\mathrm{Cu}$ during low tide in the present study might indicate the contribution of $\mathrm{Cu}$ from the upstream sites.

No formal water quality criteria exist for total heavy metals in brackish waters. Department of Environment in Malaysia has constructed a system for the criteria and standard for metals in marine waters but was limited to dissolved metals. Nevertheless, the dissolved $\mathrm{Zn}, \mathrm{Pb}, \mathrm{Cu}$, and $\mathrm{Cd}$ complied with the guideline value set by the Department of Environment, Malaysia as all the dissolved metals measured in the present study were below detection limits (data not shown).

\section{Bacteriological water quality (fecal coliform bacteria)}

Figure 9 shows that, on average, FC was lower in the main river body ranging from $1 \pm 1 \mathrm{cfu} / 100 \mathrm{ml}$ to $8 \pm 9 \mathrm{cfu} /$ $100 \mathrm{ml}$. The highest value of FC was observed at station 9, followed by station 12. Station 2 at Loba Kilong River also contained relatively higher FC with a mean of $8 \pm 7 \mathrm{cfu} /$ $100 \mathrm{ml}$. Fecal coliform was found high, but steadily decreased along Selang Sibu River from $20 \pm 24 \mathrm{cfu} /$ 
Fig. 10 Cluster of sampling stations along the Sibu Laut River and its tributaries based on the water quality data collected in a 2010 and b 2011, respectively (a) Dendrogram using Ward Method

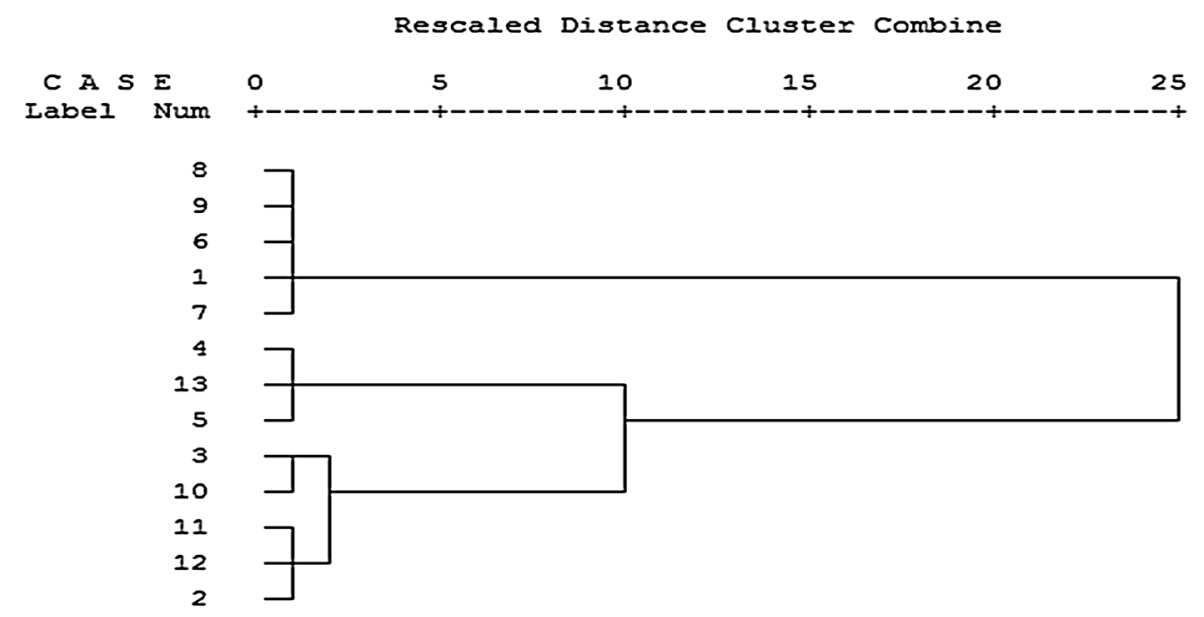

(b) Dendrogram using Ward Method

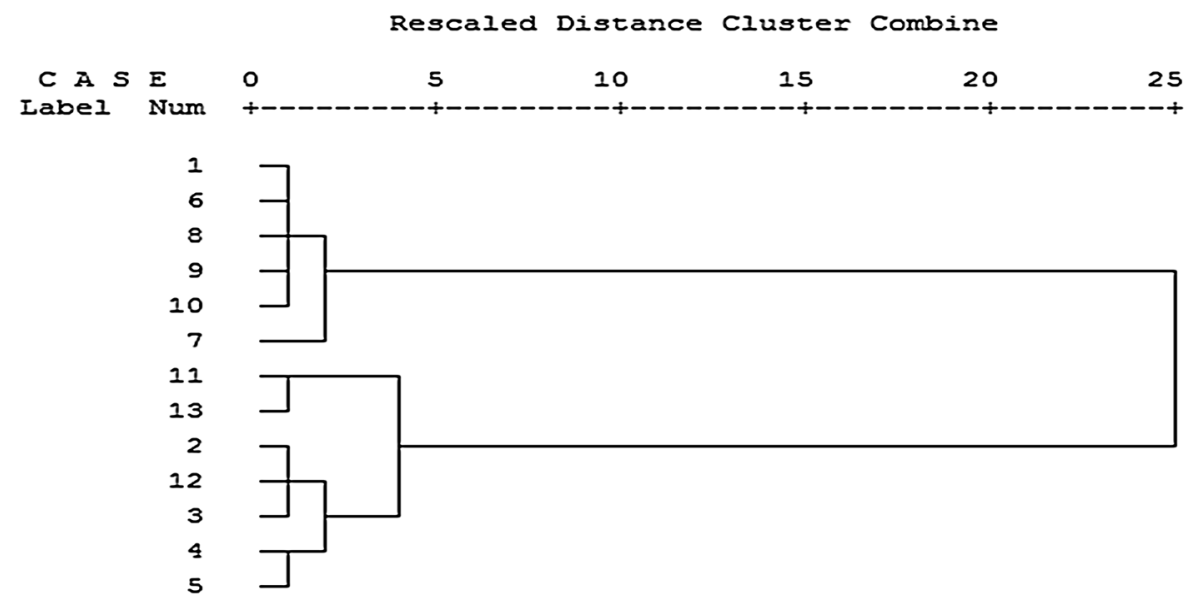

$100 \mathrm{ml}$ at station 5 to $13 \pm 15 \mathrm{cfu} / 100 \mathrm{ml}$ at station 3 . Changes in concentrations in the downstream direction reflect the attenuation of FC through sedimentation, dilution, and die-off. The results were consistent with OrtizHernandez and Saenz-Morales (1999) who demonstrated that the densities of FC were the highest in discharge samples and decreased with increasing distance from the discharge.

At low tide condition, FC was found high in Selang Sibu River especially at station 5 which is near to the discharge point of shrimp farm as illustrated in Fig. 8. Fecal coliform was steadily decreased from $39 \pm 8 \mathrm{cfu} / 100 \mathrm{ml}$ at station 5 to $26 \pm 0 \mathrm{cfu} / 100 \mathrm{ml}$ at station 3 in the sub-surface water column. Besides, FC was also found high at stations 2, 9, and 12 in both sub-surface and near-bottom water columns with an average of $14 \mathrm{cfu} / 100 \mathrm{ml}$. In addition, FC was found higher in the near-bottom water column at stations 1 , 10 , and 13 with an average of $10 \mathrm{cfu} / 100 \mathrm{ml}$. Nonetheless, FC was low at the rest of the stations during low tide, ranging from $\mathrm{BDL}$ to $6 \pm 4 \mathrm{cfu} / 100 \mathrm{ml}$. Contrary to low tide condition, FC was generally low during high tide as most of the stations contained $<2 \mathrm{cfu} / 100 \mathrm{ml}$ on average. The highest value of FC during high tide was found in near-bottom water column at station 2. Fecal coliform was not notably different between sub-surface and near-bottom water columns. Nevertheless, FC was drastically higher during low tide at most of the stations. A similar observation was described by Mallin et al. (1999) who noted an increase in the abundance of FC at or near low tide in tidal creeks that received polluted water from feeder creeks in North Carolina. Bordalo (2003) attributed the dramatic improvement in microbiological water quality to the increase in salinity during high tide in coastal beaches of Portugal.

Occasionally, slightly elevated concentration of FC ( $>10 \mathrm{cfu} / 100 \mathrm{ml}$ ) was found at stations 1, 2, 9, and 12 in the present study. Fecal coliform is typically found in fecal material originating from human or other warm-blooded 
Table 3 Loadings of environmental variables on the first six varimax-rotated PCs for water quality data collected from Sibu Laut River and its tributaries in 2010

\begin{tabular}{|c|c|c|c|c|c|c|}
\hline \multicolumn{7}{|c|}{ Rotated component matrix ${ }^{a}$} \\
\hline \multirow[t]{2}{*}{ Parameter } & \multicolumn{6}{|c|}{ Component } \\
\hline & 1 & 2 & 3 & 4 & 5 & 6 \\
\hline IP & 0.937 & & & & & \\
\hline $\mathrm{NO}_{3}{ }^{-}-\mathrm{N}$ & 0.878 & & & & & \\
\hline $\mathrm{NO}_{2}{ }^{-}-\mathrm{N}$ & 0.840 & & & & & \\
\hline Chl-a & 0.818 & & & & & 0.365 \\
\hline $\mathrm{TN}$ & 0.811 & & -0.428 & & & \\
\hline $\mathrm{pH}$ & & 0.900 & & & & \\
\hline DO & & 0.822 & & & & \\
\hline $\mathrm{BOD}_{5}$ & 0.392 & 0.767 & & & & \\
\hline Temperature & & -0.763 & -0.435 & & & \\
\hline Org-N & & & -0.819 & & & \\
\hline $\mathrm{NH}_{4}^{+}-\mathrm{N}$ & & 0.348 & 0.727 & & & \\
\hline Salinity & & & 0.637 & & 0.434 & \\
\hline Width & & & & 0.907 & & \\
\hline Depth & & & & 0.905 & & \\
\hline Transparency & & 0.412 & & 0.451 & -0.416 & \\
\hline TSS & & & & & 0.934 & \\
\hline Turbidity & & & & & 0.835 & \\
\hline $\mathrm{OP}$ & & & & & & 0.976 \\
\hline $\mathrm{TP}$ & 0.402 & & & & & 0.883 \\
\hline $\begin{array}{l}\text { Initial } \\
\text { eigenvalue }\end{array}$ & 5.814 & 3.517 & 2.593 & 1.782 & 1.497 & 1.145 \\
\hline$\%$ of variance & 30.598 & 18.513 & 13.647 & 9.381 & 7.878 & 6.028 \\
\hline Cumulative $\%$ & 30.598 & 49.111 & 62.758 & 72.139 & 80.017 & 86.045 \\
\hline
\end{tabular}

${ }^{\text {a }}$ Rotation converged in 7 iterations

animals. One of the most common FC sources is the nonpoint sources and uncontrolled discharge of sewage from densely populated urban and touristic areas (Aslan-Yilmaz et al. 2004; Ling et al. 2010b). Station 2 and station 12 received untreated waste discharge from Sibu Laut and Temenggong Village. On top of that, station 1 at downstream received polluted water from Selang Sibu River and Loba Kilong River that contained shrimp farm discharge and domestic waste. It can be concluded that the untreated sewage discharge from the adjacent villages may cause the higher counts of FC at the area. However, those villages are not large enough and generate large enough sewage to contaminate the waters in a noteworthy way when compared to other studies. Mallin et al. (2009) demonstrated that frequent excessive FC concentrations were found particularly at some of the most urbanized sites in Burnt Mill Creek (955 cfu/100 ml) while periodic high counts occurred in some rural $(536 \mathrm{cfu} / 100 \mathrm{ml})$ and suburban $(493 \mathrm{cfu} / 100 \mathrm{ml})$ locations. Besides, the geometric mean concentration of FC bacteria was $790 \mathrm{cfu} / 100 \mathrm{ml}$ in Tama
Table 4 Loadings of environmental variables on the first three varimax-rotated PCs for water quality data collected from Sibu Laut River and its tributaries in 2011

\begin{tabular}{|c|c|c|c|}
\hline \multicolumn{4}{|c|}{ Rotated component matrix ${ }^{a}$} \\
\hline \multirow[t]{2}{*}{ Parameter } & \multicolumn{3}{|c|}{ Component } \\
\hline & 1 & 2 & 3 \\
\hline Total $\mathrm{Cu}$ & -0.941 & & \\
\hline Total $\mathrm{Pb}$ & 0.929 & & \\
\hline Temperature & 0.923 & & \\
\hline Transparency & 0.808 & & 0.332 \\
\hline Turbidity & -0.658 & 0.639 & \\
\hline FC & -0.575 & & -0.546 \\
\hline Salinity & & 0.802 & \\
\hline Conductivity & 0.365 & 0.780 & 0.398 \\
\hline TDS & 0.380 & 0.766 & 0.403 \\
\hline TSS & -0.326 & 0.750 & \\
\hline $\mathrm{pH}$ & 0.565 & 0.592 & \\
\hline Total Zn & & -0.522 & 0.305 \\
\hline Width & & & 0.931 \\
\hline Depth & & & 0.875 \\
\hline DO & & 0.396 & 0.578 \\
\hline Initial eigenvalue & 5.654 & 3.828 & 1.850 \\
\hline$\%$ of variance & 37.696 & 25.518 & 12.330 \\
\hline Cumulative $\%$ & 37.696 & 63.213 & 75.544 \\
\hline
\end{tabular}

River, an urban river flowing through densely populated areas of Tokyo (Ham et al. 2009). Even more, Troussellier et al. (2004) delineated that high TTC abundances $(33,000 \mathrm{cfu} / 100 \mathrm{ml})$ were recorded in oceanic water near the large village of Guet N'dar where around 15000 fishermen live with their family.

The present mean FC value was comparatively lower when comparing to the FC abundances reported in other riverine, estuarine or coastal areas; the Sibu Laut River is far from being among the polluted sites. The mean concentration of FC bacteria in Sibu Laut River was complied with water quality standards established for FC $(<100 \mathrm{cfu} /$ $100 \mathrm{ml}$ ) by the World Health Organization (WHO 1998) or the European microbiological standards for bathing waters (Barrell et al. 2000). In fact, despite the influence of the shrimp farm wastewater, the contamination level of the Selang Sibu River appeared not so high; with the highest observed value of $50 \pm 12 \mathrm{cfu} / 100 \mathrm{ml}$ in sub-surface water at station 5 during low tide.

Hierarchical cluster analysis

Hierarchical cluster analysis was applied to detect similarities between the sampling stations along the Sibu Laut 
River and its tributaries using the sub-surface and nearbottom water quality data collected during low and high tide in 2010 and 2011, respectively. A total of 19 variables and 14 variables collected in 2010 and 2011 were first subjected to HCA, respectively. The 19 variables include the general environmental parameters, nutrients, chl- $a$, $\mathrm{TSS}$, and $\mathrm{BOD}_{5}$ collected in 2010 while the 14 variables include the general environmental parameters, total metals, and fecal coliform bacteria collected in 2011. The dendrograms showing the cluster of the sampling stations along the Sibu Laut River and its tributaries are presented in Fig. 10. The result showed that water quality was grouped into three and two groups along the Sibu Laut River and its tributaries in 2010 and 2011, respectively.

In 2010 , cluster 1 of the water quality consisted of stations $8,9,6,1$, and 7 which were all located at main river. Station 4 and station 5 which were located near to a shrimp farm at Selang Sibu River; and station 13 which was located at the left upper reach of the Sibu Laut River near to Tembangong Village were grouped into cluster 2 . Lastly, cluster 3 consisted of sampling stations 3, 10, 11, 12 , and 2, which are mainly located on the tributaries of the Sibu Laut River. On the other hand, water quality collected in 2011 was grouped into two major clusters which were the main stem of the Sibu Laut River and the tributaries of the river. The cluster analysis further confirmed that the effluents from the shrimp farm near Selang Sibu River consisted relatively higher nutrients compared to total metals and fecal coliform bacteria; hence, the stations near the shrimp farm were dissimilar with the other stations located on the main stem and other tributaries.

\section{Principal component analysis}

Principal component analysis was conducted to characterize the loadings of 19 and 14 variables in the water quality of the Sibu Laut River and its tributaries in 2010 and 2011, respectively. The KMO measure of sampling adequacy obtained was 0.445 and 0.760 for water samples in 2010 and 2011, respectively. Six PCs were obtained for the water quality in 2010 (Table 3); and three PCs were obtained for the water quality in 2011 (Table 4), with eigenvalues larger than 1, explaining 86.045 and $75.544 \%$ of the total variance, respectively.

The first PC for water quality in 2010 has high positive loadings for the IP, $\mathrm{NO}_{3}{ }^{-}-\mathrm{N}, \mathrm{NO}_{2}{ }^{-}-\mathrm{N}$, chl- $a, \mathrm{TN}, \mathrm{BOD}_{5}$, and TP, accounted for $30.598 \%$ of total variance. The second PC accounted for $18.513 \%$ of the total variance and positively loaded with $\mathrm{pH}, \mathrm{DO}, \mathrm{BOD}_{5}, \mathrm{NH}_{4}{ }^{+}-\mathrm{N}$, and transparency; but negatively loaded with temperature. The third PC which contributed $13.647 \%$ of the total variance showed positive loadings on $\mathrm{NH}_{4}{ }^{+}-\mathrm{N}$ and salinity, and negative loadings on TN, Org-N, and temperature. Positive loading of width, depth, and transparency was observed in PC 4 which accounted for $9.381 \%$ of total variance. The PC 5 and PC 6 contributed 7.878 and $6.028 \%$ of the total variance, respectively. The PC 5 was found to be positively loaded with salinity, TSS, and turbidity; and negatively loaded with transparency. Positive loading was observed in chl- $a$, TP, and OP in the last PC.

In the present study, PCA showed positive loadings on nutrients, phytoplankton, and organic matter indicated that those enrichments on the Sibu Laut River were derived from the same sources which were mainly regulated by the shrimp farm effluent and riverine runoff of domestic sewage. The positive loading of chlorophyll and nutrients indicated that high chl- $a$ concentration may be due to the availability of higher concentration of nutrients which favor their growth. The $\mathrm{BOD}_{5}$ and $\mathrm{NH}_{4}{ }^{+}-\mathrm{N}$ were positively loaded in PC 2 indicated that they are possibly derived from the same sources particulary the shrimp farm. The oxidation of $\mathrm{NH}_{4}{ }^{+}-\mathrm{N}$ contributes to high $\mathrm{BOD}_{5}$, and the process is strongly regulated by $\mathrm{pH}, \mathrm{DO}$, and temperature as $\mathrm{BOD}_{5}$ and $\mathrm{NH}_{4}{ }^{+}-\mathrm{N}$ are positively loaded with $\mathrm{pH}$ and DO, but negatively loaded with temperature. Positive loading on salinity and negative loadings of TN and Org-N were observed in the present study. In other word, TN and Org-N concentrations decreased as salinity increased which may be the result of mixing those nutrients with high salinity coastal water as depicted by Whitall et al. (2010). On the other hand, the positive loadings on salinity, TSS, and turbidity indicated that suspended solids were high in the downstream due to the movement of water in and out of the estuary by tides, causing fine particles to mix and be stirred up.

In 2011, PC 1 accounted for $37.696 \%$ of the total variance, showing positive loadings on total $\mathrm{Pb}$, temperature, transparency, conductivity, TDS, and $\mathrm{pH}$; but negatively loaded with total $\mathrm{Cu}$, turbidity, $\mathrm{FC}$, and TSS. Positive loadings on turbidity, salinity, conductivity, TDS, TSS, pH, and DO; but negatively loaded with total $\mathrm{Zn}$ was observed on PC 2 which contributed $25.518 \%$ of the total variance. The contribution of PC 3 to the total variance was $12.330 \%$ and positively loaded with transparency, conductivity, TDS, total Zn, depth, width and DO; but has a negative loading on FC.

Positive loadings on $\mathrm{pH}$, salinity, conductivity, TDS, and negative loadings on total $\mathrm{Cu}$ and total $\mathrm{Zn}$ were observed in the PCA. This phenomenon indicated that the most important sources of these metals could be the riverine and estuarine discharge, or the anthropogenic sources in the upstream. The decrease in metals concentration is probably the result of the dilution by seawater (Norton et al. 1984) or the precipitation of metals in the tidal area with higher $\mathrm{pH}$ (Grande et al. 1999). Positive loadings on temperature, conductivity, TDS, total $\mathrm{Pb}$, and total $\mathrm{Zn}$; and 
negative loading of FC were observed in the PCA. This agrees well with the previous studies that increase in temperature (Chigbu et al. 2004; Noble et al. 2004), salinity (Hamzah et al. 2011; Yayintaş et al. 2007), and heavy metals (Malik and Ahmad 2002; Jana and Bhattacharya 1988) were harmful to FC survival in natural environments. Besides, the negative loadings on FC, turbidity and TSS are not surprising. Transport of FC via resuspension of the sediments through the storm or tidal actions into the overlying water column is an important mechanism in the aquatic environment (Brauwere et al. 2011; Ouattara et al. 2011) as FC has longer survival in association with sediment particles (Ishii et al. 2007; Lee et al. 2006).

\section{Conclusions}

Sibu Laut River is a highly dynamic, tidally dominated and well-oxygenated river with relatively consistent temperature. The $\mathrm{pH}$ value of the water is well within range and demonstrates an increasing trend from upstream to downstream. Total suspended solids and turbidity are low in subsurface waters; show increasing values from upstream to downstream, but may be high at the intersection between freshwater and seawater. TDS and conductivity concentrations show changes with river miles, with higher concentration were found in near-bottom water column and in high tide condition. The spatial distribution pattern of the parameters studied indicates substantial inputs of contaminants possibly from shrimp farms as well as domestic sewage from villages nearby Sibu Laut River. The higher elemental concentrations which included chl- $a, \mathrm{BOD}_{5}$, nitrogen, phosphorus, and FC were associated with the stations near the intake creek of shrimp farm effluent in Selang Sibu River, and sewage discharge points of the villages of Sibu Laut, Telaga Air, and Temenggong. Nevertheless, the shrimp farm effluent had no major influence on heavy metals pollution. Sibu Laut River was characterized as oligotrophic and/or mesotrophic status according to chl- $a$ and TP inputs, but was characterized as hypertrophic status according to the TN input. Nitrate concentrations in the Sibu Laut River violated the national standard, while occasional violation of $\mathrm{NO}_{2}{ }^{-} \mathrm{N}$ concentration was observed in near-bottom water column during low tide. Other water quality criteria in the Sibu Laut River are well within range and complied with the international and national standard.

Acknowledgments The authors appreciate the financial support provided by the Malaysian Ministry of Science, Technology and Innovation (MOSTI) through E-Science Grant; 06-01-09-SF0026, and Ministry of Higher Education (MOHE) through FRGS Grant; FRGS/
07(02)/749/2010(35), and the facilities provided by Universiti Malaysia Sarawak.

Open Access This article is distributed under the terms of the Creative Commons Attribution License which permits any use, distribution, and reproduction in any medium, provided the original author(s) and the source are credited.

\section{References}

Amaraneni SR (2006) Distribution of pesticides, PAHs and heavy metals in prawn ponds near Kolleru Lake Wetland, India. Environ Int 32(3):294-302

APHA (2005) Standard methods for the examination of water and wastewater, 21st edn. APHA, AWWA, and WEF, USA

Aslan-Yilmaz A, Okus E, Ovez S (2004) Bacteriological indicators of anthropogenic impact prior to and during the recovery of water quality in an extremely polluted estuary, Golden Horn, Turkey. Mar Pollut Bull 49(11-12):951-958

Balls PW, Laslett RE, Price NB (1994) Nutrient and trace metal distributions over a complete semi-diurnal tidal cycle in the Forth Estuary, Scotland. Neth J Sea Res 33(1):1-17

Barrell RA, Hunter PR, Nichols G (2000) Microbiological standards for water and their relationship to health risk. Commun Dis Public Health 3(1):8-13

Bennasser L, Fekhaoui M, Benoit-Guyod JL, Merlin G (1997) Influence of tide on water quality of lower Sebou polluted by Gharb plain wastes (Morocco). Water Res 31(4):859-867

Bonadonna L, Briancesco R, Coccia AM, Semproni M, Stewardson D (2002) Occurrence of potential bacterial pathogens in coastal areas of the Adriatic Sea. Environ Monit Assess 77:31-49

Bordalo AA (2003) Microbiological water quality in urban coastal beaches: the influence of water dynamics and optimization of the sampling strategy. Water Res 37(13):3233-3241

Braga ES, Bonetti CVDH, Burone L, Filho JB (2000) Eutrophication and bacterial pollution caused by industrial and domestic wastes at the Baixada Santista estuarine system-Brazil. Mar Pollut Bull 40(2):165-173

Bricker SB, Clement CG, DE Pirhalla, Orlando SP, Farrow DRG (1999) National Estuarine Eutrophication Assessment: effects of nutrient enrichment in the Nation's Estuaries. NOAA, National Ocean Service, Special Projects Office and the National Centers for Coastal Ocean Science. Silver Spring, MD

Burgos MG, Rainbow PS (2001) Availability of cadmium and zinc from sewage sludge to the flounder, Platichthys flesus, via a marine food chain. Mar Environ Res 51(5):417-439

Cabral JP, Marques C (2006) Faecal coliform bacteria in Febros River (Northwest Portugal): temporal variation, correlation with water parameters, and species identification. Environ Monit Assess $118(1-3): 21-36$

Caccia VG, Millero FJ (2003) The distribution and seasonal variation of dissolved trace metals in Florida Bay and adjacent waters. Aquat Geochem 9(1):111-144

Camargo JA, Alonso A, Salamanca A (2005) Nitrate toxicity to aquatic animals: a review with new data for freshwater invertebrates. Chemosphere 58:1255-1267

Canadian Council of Ministers of the Environment (2003) Canadian Water Quality Guidelines for the Protection of Aquatic Life: Nitrate Ion. CCMI, Winnipeg

Chigbu P, Gordon S, Strange T (2004) Influence of inter-annual variations in climatic factors on fecal coliform levels in Mississippi Sound. Water Res 38(20):4341-4352 
Cotner JBJ, Wetzel RG (1992) Uptake of dissolved inorganic and organic phosphorus compounds by phytoplankton and bacterioplankton. Limnol Oceanogr 37(2):232-243

Davis JR, Koop K (2006) Eutrophication in Australian rivers, reservoirs and estuaries - a southern hemisphere perspective on the science and its implications. Hydrobiologia 559(1):23-76

De Brauwere A, De Brye B, Servais P, Passerat J, Deleersnijder E (2011) Modelling Escherichia coli concentrations in the tidal Scheldt River and estuary. Water Res 45(9):2724-2738

Del-Pilar-Ruso Y, De-la-Ossa-Carretero JA, Loya-Fernández A, Ferrero-Vicente LM, Giménez-Casalduero F, Sánchez-Lizaso JL (2009) Assessment of soft-bottom polychaeta assemblage affected by a spatial confluence of impacts: sewage and brine discharges. Mar Pollut Bull 58(5):776-782

Department of Environment (2010) Malaysia marine water quality criteria and standard. DOE, Malaysia. http://www.doe.gov.my/ portal/water-marine-marine-island-marine-water/malaysia-interimmarine-water-quality-standard/ Accessed 20 Oct 2012

Diaz RJ, Rosenberg R (1995) Marine benthic hypoxia: a review of its ecological effects and the behavioural responses of benthic macrofauna. Oceanogr Mar Biol 33:245-303

Djuikom E, Njine T, Nola M, Sikati V, Jugnia LB (2006) Microbiological water quality of the Mfoundi River watershed at Yaoundé, Cameroon, as inferred from indicator bacteria of fecal contamination. Environ Monit Assess 122(1-3):171-183

Dorsey JH, Carmona-Galindo VD, Leary C, Huh J, Valdez J (2012) An assessment of fecal indicator and other bacteria from an urbanized coastal lagoon in the City of Los Angeles, California, USA. Environ Monit Assess 185(3):2647-2669

Du Laing G, Moortel AVD, Lesage E, Tack FMG, Verloo MG (2008) Chapter 11: factors affecting metal accumulation, mobility and availability in intertidal wetlands of the Scheldt Estuary (Belgium). In: Vymazal J (ed) Wastewater treatment, plant dynamics and management. Springer Science + Business Media B.V, Netherlands, pp 121-133

Fianko JR, Osae S, Adomako D, Adotey DK, Serfor-Armah Y (2007) Assessment of heavy metal pollution of the Iture Estuary in the central region of Ghana. Environ Monit Assess 131(1-3):467-473

Grande JA, Borrego J, Morales JA (1999) A study of heavy metal pollution in the Tinto-Odiel Estuary in Southwestern Spain using factor analysis. Environ Geol 39(10):1095-1101

Hadibarata T, Abdullah F, Yusoff ARM, Ismail R, Azman S, Adnan N (2012) Correlation study between land use, water quality, and heavy metals $(\mathrm{Cd}, \mathrm{Pb}$, and $\mathrm{Zn})$ content in water and green lipped mussels Perna viridis (Linnaeus.) at the Johor Strait. Water Air Soil Poll 223(6):3125-3136

Ham YS, Kobori H, Takasago M (2009) Effects of combined sewer overflow and stormwater on indicator bacteria concentrations in the Tama River due to the high population density of Tokyo metropolitan area. Environ Monit Assess 152(1-4):459-468

Hamzah A, Hattasrul Y (2008) Water quality and bacterial study in Tasik Chini, Pahang. In: Sengupta M, Dalwani R (eds) Proceedings of Taal 2007: The 12th World Lake Conference. ILEC, Japan, pp 184-189

Hamzah A, Kipli SH, Ismail SR, Una R, Sarmani S (2011) Microbiological study in coastal water of Port Dickson, Malaysia. Sains Malays 40(2):93-99

Hatje V (2003) Particulate trace metal and major element distributions over consecutive tidal cycles in Port Jackson Estuary, Australia. Environ Geol 44:231-239

Ho AYT, Xu J, Yin K, Yuan X, He L, Jiang Y, Lee JHW et al (2008) Seasonal and spatial dynamics of nutrients and phytoplankton biomass in Victoria Harbour and its vicinity before and after sewage abatement. Mar Pollut Bull 57(6-12):313-324

Howarth RW, Marino R (2006) Nitrogen as the limiting nutrient for eutrophication in coastal marine ecosystems: evolving views over three decades. Limnol Oceanogr 51(1, part 2):364-376
Huang XP, Huang LM, Yue WZ (2003) The characteristics of nutrients and eutrophication in the Pearl River Estuary, South China. Mar Pollut Bull 47(1-6):30-36

Ishii S, Hansen DL, Hicks RE, Sadowsky MJ (2007) Beach sand and sediments are temporal sinks and sources of Escherichia coli in Lake Superior. Environ Sci Technol 41(7):2203-2209

Jana S, Bhattacharya DN (1988) Effect of heavy metals on growth population of a fecal coliform bacterium Escherichia coli in aquatic environment. Water Air Soil Poll 38(20):251-254

Jonas PJC, Millward GE (2010) Metals and nutrients in the Severn Estuary and Bristol Channel: contemporary inputs and distributions. Mar Pollut Bull 61(1-3):52-67

Jones RC, Kelso DP, Schaeffer E (2008) Spatial and seasonal patterns in water quality in an embayment-mainstem reach of the tidal freshwater Potomac River, USA: a multiyear study. Environ Monit Assess 147(1-3):351-375

Juahir H, Zain SM, Yusoff MK, Hanidza TIT, Armi ASM, Toriman ME, Mokhtar M (2011) Spatial water quality assessment of Langat River Basin (Malaysia) using environmetric techniques. Environ Monit Assess 173(1-4):625-641

Kovačić A, Tripković I, Galov A, Zitko T (2011) Distribution of microbiological indicators of fecal pollution in the riverine substrates. Environ Monit Assess 172(1-4):623-630

Kress N, Herut B, Galil BS (2004) Sewage sludge impact on sediment quality and benthic assemblages off the Mediterranean coast of Israel-a long-term study. Mar Environ Res 57(3):213-233

Kurun A, Balkis H, Balkis N (2007) Accumulations of total metal in dominant shrimp species (Palaemon adspersus, Palaemon serratus, Parapenaeus longirostris) and bottom surface sediments obtained from the northern inner shelf of the Sea of Marmara. Environ Monit Assess 135(1-3):353-367

La Rosa T, Mirto S, Favaloro E, Savona B, Sarà G, Danovaro R, Mazzola A (2002) Impact on the water column biogeochemistry of a Mediterranean mussel and fish farm. Water Res 36(3):713-721

Lacerda LD, Campos RC, Santelli RE (2013) Metals in water, sediments, and biota of an offshore oil exploration area in the Potiguar Basin, Northeastern Brazil. Environ Monit Assess 185(5):4427-4447

Lee CM, Lin TY, Lin CC, Kohbodi GA, Bhatt A, Lee R, Jay JA (2006) Persistence of fecal indicator bacteria in Santa Monica Bay Beach sediments. Water Res 40(14):2593-2602

Lefebvre A, Guiselin N, Barbet F, Artigas FL (2011) Long-term hydrological and phytoplankton monitoring (1992-2007) of three potentially eutrophic systems in the Eastern English Channel and the Southern Bight of the North Sea. ICES J Mar Sci 68(10):2029-2043

Ling TY, Siew TF, Lee N (2010a) Quantifying pollutants from household wastewater in Kuching, Malaysia. World Appl Sci J 8(4):449-456

Ling TY, Srikaran R, Kho CP, Lee N (2010b) Organic matter, nutrients and trace metals of Serin River. World Appl Sci J 8(4):496-502

Lourino-Cabana B, Billon G, Magnier A, Prygiel E, Baeyens W, Prygiel J, Mikkelsen O, Ouddane B (2011) Evidence of highly dynamic geochemical behaviour of zinc in the Deûle River (Northern France). J Environ Monit 13:2124-2133

Madhu NV, Balachandran KK, Martin GD, Jyothibabu R, Thottathil SD, Nair M, Joseph T et al (2010) Short-term variability of water quality and its implications on phytoplankton production in a tropical estuary (Cochin Backwaters-India). Environ Monit Assess 170(1-4):287-300

Malaysian Meteorological Department (2012) General climate of Malaysia. MMD Malaysia. http://www.met.gov.my/index.php?option= com_content\&task=view\&id=75\&Itemid=1089 Accessed 20 Oct 2012 
Malik A, Ahmad M (2002) Seasonal variation in bacterial flora of the wastewater and soil in the vicinity of industrial area. Environ Monit Assess 73(3):263-273

Mallin MA, Esham EC, Williams KE, Nearhoof JE (1999) Tidal stage variability of fecal coliform and chlorophyll a concentrations in coastal creeks. Mar Pollut Bull 38(5):414-422

Mallin MA, Johnson VL, Ensign SH (2009) Comparative impacts of stormwater runoff on water quality of an urban, a suburban, and a rural stream. Environ Monit Assess 159(1-4):475-491

Meyer-Reil LA, Koster M (2000) Eutrophication of marine waters: effects on benthic microbial communities. Mar Pollut Bull 41(1-6):255-263

Molvaer J, Knutzen J, Magnusson J, Rygg B, Skei J, Sorensen J (1997). Environmental Quality Classification in Fjords and Coastal Areas. Statens Forurensningstilsyn TA-1467, Norway

Nduka JK, Orisakwe OE (2009) Effect of effluents from warri refinery petrochemical company WRPC on water and soil qualities of "contiguous host" and "impacted on communities" of Delta State, Nigeria. Open Environ Pollut Toxicol J 1(1):11-17

Nixon SW (1995) Costal marine eutrophication-a definition, social causes, and future concerns. Ophelia 41:199-219

Noble RT, Lee IM, Schiff KC (2004) Inactivation of indicator microorganisms from various sources of faecal contamination in seawater and freshwater. J Appl Microbiol 96(3):464-472

Norton MG, Rowlatt SM, Nunny RS (1984) Sewage sludge dumping and contamination of Liverpool Bay sediments. Estuar Coast Shelf Sci 19(1):69-87

Ortiz-Hernandez MC, Saenz-Morales R (1999) Effects of organic material and distribution of fecal coliforms in Chetumal Bay, Quintana Roo, México. Environ Monit Assess 55:423-434

Otero XL, Vidal-Torrado P, Calvo de Anta RM, Macías F (2005) Trace elements in biodeposits and sediments from mussel culture in the Ria de Arousa (Galicia, NW Spain). Environ pollut (Barking, Essex: 1987) 136(1):119-134

Ouattara NK, Passerat J, Servais P (2011) Faecal contamination of water and sediment in the rivers of the Scheldt drainage network. Environ Monit Assess 183(1-4):243-257

Paez-Osuna F, Guerrero-Galvan SR, Ruiz-Fernandez AC (1998) The environmental impact of shrimp aquaculture and the coastal pollution in Mexico. Mar Pollut Bull 36(1):65-75

Pan Y, Subba Rao DV (1997) Impacts of domestic sewage effluent on phytoplankton from Bedford Basin, Eastern Canada. Mar Pollut Bull 34(12):1001-1005

Parnell PE (2003) The effects of sewage discharge on water quality and phytoplankton of Hawaiian coastal waters. Mar Environ Res 55:293-311

Parsons TR, Maita Y, Lalli CM (1984) A manual of chemical and biological methods for seawater analysis. Pergamon Press, Oxford

Pinckney JL, Paerl HW, Tester P, Richardson TL (2001) The role of nutrient loading and eutrophication in estuarine ecology. Environ Health Persp 109(5):699-706

Pomeroy RL, Smith EE, Grant CM (1965) The exchange of phosphate between estuarine water and sediments. Limnol Oceanogr $\mathrm{X}(2): 167-172$

Pope ND, Langston WJ (2011) Sources, distribution and temporal variability of trace metals in the Thames Estuary. Hydrobiologia 672(1):49-68

Reopanichkul P, Carter RW, Worachananant S, Crossland CJ (2010) Wastewater discharge degrades coastal waters and reef communities in Southern Thailand. Mar Environ Res 69:287-296

Ribeiro C, Kjerfve B (2002) Anthropogenic influence on the water quality in Guanabara Bay, Rio de Janeiro, Brazil. Reg Environ Change 3(1-3):13-19
Rippey B (1982) Sediment-water interactions of $\mathrm{Cu}, \mathrm{Zn}$ and $\mathrm{Pb}$ discharged from a domestic waste water source into a Bay of Lough Neagh, Northern Ireland. Environ Pollut B 3:199-214

Rubin AJ, Elmaraghy GA (1977) Studies on the toxicity of ammonia, nitrate and their mixtures to guppy fry. Water Res 11:927-935

Satpathy KK, Mohanty AK, Natesan U, Prasad MVR, Sarkar SK (2010) Seasonal variation in physicochemical properties of coastal waters of Kalpakkam, East Coast of India with special emphasis on nutrients. Environ Monit Assess 164(1-4):153-171

Seitzinger S, Sanders R (1997) Contribution of dissolved organic nitrogen from rivers to estuarine eutrophication. Mar Ecol-Prog Ser 159:1-12

Shahidul IM, Jahangir SM, Yamamoto T, Abdul WM, Tanaka M (2004) Water and sediment quality, partial mass budget and effluent $\mathrm{N}$ loading in coastal brackish water shrimp farms in Bangladesh. Mar Pollut Bull 48(5-6):471-485

Shin JY, Artigas F, Hobble C, Lee YS (2012) Assessment of anthropogenic influences on surface water quality in urban estuary, Northern New Jersey: multivariate approach. Environ Monit Assess 185(3):2777-2794

Simeonov V, Stratis JA, Samara C, Zachariadis G, Voutsa D, Anthemidis A, Sofoniou M et al (2003) Assessment of the surface water quality in Northern Greece. Water Res 37(17):4119-4124

Smith VH, Tilman GD, Nekola JC (1999) Eutrophication: impacts of excess nutrient inputs on freshwater, marine, and terrestrial ecosystems. Environ Pollut (Barking, Essex: 1987) 100(13):179-196

Sondergaard M, Jensen PJ, Jeppesen E (2001) Retention and internal loading of phosphorus in shallow, eutrophic lakes. Sci World J $1: 427-442$

Song MW, Huang P, Li F, Zhang H, Xie KZ, Wang XH, He GX (2011) Water quality of a tributary of the Pearl River, the Beijiang, Southern China: implications from multivariate statistical analyses. Environ Monit Assess 172(1-4):589-603

Sundaray SK, Nayak BB, Kanungo TK, Bhatta D (2012) Dynamics and quantification of dissolved heavy metals in the Mahanadi River estuarine system, India. Environ Monit Assess 184(2):1157-1179

Thomas Y, Courties C, Helwe YE, Herbland A, Lemonnier H (2010) Spatial and temporal extension of eutrophication associated with shrimp farm wastewater discharges in the New Caledonia Lagoon. Mar Pollut Bull 61(7-12):387-398

Trott LA, Alongi DM (2000) The impact of shrimp pond effluent on water quality and phytoplankton biomass in a tropical mangrove estuary. Mar Pollut Bull 40(11):947-951

Troussellier M, Got P, Bouvy M, M'Boup M, Arfi R, Lebihan F, Monfort P et al (2004) Water quality and health status of the Senegal River Estuary. Mar Pollut Bull 48(9-10):852-862

USEPA (2003). Ambient Water Quality Criteria for Dissolved Oxygen, Water Clarity and Chlorophyll a for the Chesapeake Bay and Its Tidal Tributaries. EPA 903-R-03-002. EPA, United States

USEPA (2009). National recommended water quality criteria. USEPA. http://water.epa.gov/scitech/swguidance/standards/ current/. Accessed 20 October 2012

Wetlands International (2013). Ramsar sites information service. wetlands international. http://ramsar.wetlands.org/ Accessed 3 March 2014

Whitall D, Hively WD, Leight AK, Hapeman CJ, McConnell LL, Fisher T, Rice CP et al (2010) Pollutant fate and spatio-temporal variability in the Choptank River Estuary: factors influencing water quality. Sci Total Environ 408(9):2096-2108

WHO (1998). Guidelines for safe recreational-water environments. WHO/EOS/98. WHO, Geneva 
Wickins JF (1976) The tolerance of warm-water prawns to recirculated water. Aquaculture 9:19-37

Wu RSS, Lam KS, MacKay DW, Lau TC, Yam V (1994) Impact of marine fish farming on water quality and bottom sediment: a case study in the sub-tropical environment. Mar Environ Res 38(2):115-145

Xu J, Ho AYT, Yin K, Yuan X, Anderson DM, Lee JHW, Harrison PJ (2008) Temporal and spatial variations in nutrient stoichiometry and regulation of phytoplankton biomass in Hong Kong waters: influence of the Pearl River outflow and sewage inputs. Mar Pollut Bull 57(6-12):335-348

Yayintaş OT, Yilmaz S, Türkoğlu M, Colakoğlu FA, Cakir F (2007) Seasonal variation of some heavy metal pollution with environmental and microbiological parameters in sub-basin of Kocabas
Stream (Biga, Canakkale, Turkey) by ICP-AES. Environ Monit Assess 134(1-3):321-331

Yin K, Harrison PJ (2007) Influence of the Pearl River Estuary and vertical mixing in Victoria Harbor on water quality in relation to eutrophication impacts in Hong Kong waters. Mar Pollut Bull 54(6):646-656

Young K, Morse GK, Scrimshaw MD, Kinniburgh JH, MacLeod CL, Lester JN (1999) The relation between phosphorus and eutrophication in the Thames catchment, UK. Sci Total Environ 228:157-183

Zhang D, Zhang X, Tian L, Ye F, Huang X, Zeng Y, Fan M (2012) Seasonal and spatial dynamics of trace elements in water and sediment from Pearl River Estuary, South China. Environ Earth Sci 68(4):1053-1063 